\title{
Indigenous Environmental Justice and Sustainability: What Is Environmental Assimilation?
}

\author{
Stephen R. J. Tsuji
}

Citation: Tsuji, S.R.J. Indigenous

Environmental Justice and

Sustainability: What Is

Environmental Assimilation? Sustainability 2021, 13, 8382.

https://doi.org/10.3390/su13158382

Academic Editors: Troy D. Abel,

Debra J. Salazar, Patrick D. Murphy and Jonah White

Received: 1 June 2021

Accepted: 20 July 2021

Published: 27 July 2021

Publisher's Note: MDPI stays neutral with regard to jurisdictional claims in published maps and institutional affiliations.

Copyright: (C) 2021 by the author. Licensee MDPI, Basel, Switzerland. This article is an open access article distributed under the terms and conditions of the Creative Commons Attribution (CC BY) license (https:// creativecommons.org/licenses/by/ $4.0 /)$.
School of Environmental Studies, Queen's University, Kingston, ON K7L 3N6, Canada; 20srjt@queensu.ca

\begin{abstract}
Canada has a long history of assimilative efforts with respect to Indigenous peoples. Legal assimilation efforts occurred on two fronts: the voluntary and involuntary enfranchisement of First Nations people, and the dissolution of First Nations reserve lands. Cultural assimilation occurred through the residential school system, and the removal of Indigenous children from their homes by Canadian child welfare agencies in the "sixties scoop". Another form of assimilation is through environmental assimilation. I define environmental assimilation as changes to the environment through development, to the extent whereby the environment can no longer support Indigenous cultural activities. Herein, I examine environmental assimilation in northern Ontario, Canada. The "taken-up" clause in Treaty No. 9, the "Exemption Orders" in the Far North Act, the "Except" stipulation in the Mining Amendment Act, and the unilateral streamlining of projects in the Green Energy Act and the COVID-19 Economic Recovery Act-these pieces of legislation pose threats to the environment and serve to facilitate the reality of contemporary environmental assimilation of First Nations.
\end{abstract}

Keywords: indigenous; environmental justice; sustainability; legal assimilation; cultural assimilation; environmental assimilation; first nations; subarctic; Canada

\section{Introduction \\ 1.1. Indigenous Environmental Justice}

In the United States (US), the 1980s environmental justice movement emerged from the Civil Rights Movement of the 1960s; the environmental-justice issue related to hazardouswaste facilities being disproportionately sited in racialized neighbourhoods [1-3]. Henceforth, the US Environmental Protection Agency [3] (p. 1) defined environmental justice as:"the fair treatment and meaningful involvement of all people regardless of race, color, national origin, or income, with respect to the development, implementation, and enforcement of environmental laws, regulations, and policies". Since then, the environmentaljustice movement has branched into several other facets, the core of which are distributive justice, procedural justice, and recognition justice. In Scott's case, he described environmental justice as both a theoretical lens that takes into account the sharing (distributive dimension) of environmental costs and benefits "associated with environmental policy and natural resource development decisions, and the extent to which the decision -making has meaningfully included the participation of affected communities [procedural dimension]" [4] (p. 3); and a social movement within Indigenous communities that emphasizes "the interconnectedness of people and their environments, and the narrowness and shortsightedness of the approach that would separate the well-being of ecosystems from those who depend on them." [4] (p. 4). Through this realization of relations, procedural aspects lapse into the realm of recognition-based justice ideals. Another procedural dimension to environmental justice is that everyone should have full access to information used for decision-making purposes, and enough time to analyse the information in order to make informed comments [5].

Meanwhile, Indigenous environmental justice directly addresses the need for a recognition-based approach that presents a unique framework based on Indigenous understand- 
ings that see the Earth is alive and everything is imbued with spirit [6]. It then follows that "a reciprocal set of duties and responsibilities [Indigenous laws and codes of conduct] between humans and the rest of the natural world exists such that, assuming these obligations are consistently met, relations between human and non-human entities are maintained in a healthy [harmonious or reciprocal] balance" [6] (p. 35).

\subsection{Sustainability}

Although the environmental justice and sustainable development concepts both emerged in the 1980s, their geneses were profoundly different. Environmental justice utilized a bottom-up approach from the disadvantaged communities themselves, while the sustainability agenda was top-down due to largely having emerged from international governmental organizations, think-tanks, and nongovernmental organizations [7]. The pillars of sustainability were first described at the United Nations' Stockholm Conference in 1972 [8] as broad areas of categorization thought to form the basis for sustainability [9]. Initially, the focal point was solely on ecology; however, there have been numerous notable shifts in focus and inclusion over the decades since then. In 1987, society and economy were added as pillars alongside the founding pillar of ecology during the World Commission on Environmental Development [10]. From then on, the United Nations World Commission on Environment and Development defined sustainable development as "development that meets the needs of the present without compromising the ability of future generations to meet their own needs" [11] (c.2 (1)).

The three-pillar model of sustainability would persist into the next millennium, but due to the evolving definition of the environment, a number of arguments have been made for the inclusion of other pillars. One such argument was proposed in 2002 during the World Public Meeting on Culture [12] where they put forth their argument for the inclusion of culture as a pillar of sustainability in the context of Agenda 21 [13]. It would not be until 2004 that culture officially received recognition, and cultural aspects were added to Agenda 21, which is now referred to as Culture 21 [14]. While there are other instances of arguments being made for different additions to the pillars, the point of focus for this section is to identify that culture is a recognized pillar of sustainability and the accompanying history leading to its inclusion. Lastly, the opposite of cultural sustainability is cultural loss or assimilation. Cultural loss or assimilation can take on many forms, such as loss of language, history, or other types of cultural values and identity (see Section 2.1.2 for more details).

\subsection{Environmental Assimilation}

In this article, I introduce the term "environmental assimilation" to the academic literature on sustainability. I define environmental assimilation as changes to the environment through development, to the extent to which the environment can no longer support Indigenous cultural activities, either partially or fully. Environmental assimilation can be both a process along a continuum and an endpoint. In the words of the Nishiiyuu Council of Elders [15]: "what is done to our land is done to our people". In essence, if colonizers develop on Indigenous homelands and assimilate in part or wholly Indigenous homelands into the colonial landscape through development, in effect, the colonizers are also assimilating the Indigenous people through environmental assimilation.

Herein, I am the first to examine environmental assimilation in northern Ontario, Canada in relation to Indigenous environmental justice and sustainability. First, it is important to present a brief background section about Canadian assimilative policies, followed by The James Bay Treaty-Treaty No. 9 subsection, and the subsection on recent Government of Ontario assimilative legislation. Next, a brief methods section is presented detailing the geographic and cultural scope of the present study, along with data collection and analyses. This section is followed by results and discussion based on data analyses relevant to the research aim, and the conclusions of the study are lastly presented. 


\section{Background}

\subsection{Canadian Policies of Assimilation}

Historically, "Indian" was a term erroneously used in reference to the First Nations people of North America because the European colonizers wrongly believed that they had arrived on the Indian subcontinent. Nonetheless, I use the term "Indian" in reference to historical-government documents and First Nations or Indigenous people.

Canada employs a federated system of government whereby different levels of government have specific jurisdictional responsibilities. Under the Canadian Constitution Act, 1867 [16] (Section 92A(1)), "Non-Renewable Natural Resources, Forestry Resources and Electrical Energy" fell under the exclusive powers of the provincial legislatures (e.g., Ontario). Additionally, as detailed in the Canadian Constitution Act, 1867 [16] (Section 91(24)), "Indians, and Lands reserved for the Indians" fell under the purview of the Dominion of Canada. Thus, the Government of Canada had sole responsibility with respect to "Indians" and enacted many pieces of legislation to assimilate First Nations people, and this endeavour was part of a national agenda. Assimilation policy in Canada with respect to "Indians" had both a legal and cultural component [17]. Legal assimilation refers to the loss of "Indian" status in Canada; cultural assimilation is the loss of the distinguishable characteristics of a cultural group [17]. Below, brief descriptions of the Government of Canada's assimilative efforts are given.

\subsubsection{Legal Assimilation}

Prior to the confederation of the provinces to form the Dominion of Canada in 1867, there already existed as of 1830 an "Indian civilization" agenda [18]. Policies included "Indian" land cession through the signing of treaties with the establishment of "Indian" reserves (now called First Nations, and set aside for the exclusive use of First Nations people), and the educating of "Indians" in day and industrial schools, and lastly residential schools [18]. In 1850, legislation was passed by the Province of Canada-that is, Canada West, the forerunner of Ontario, and Canada East, which would later become Quebecthat defined, albeit ambiguously, who was an "Indian" or, more accurately, who was not an "Indian" [18,19]. By first defining who was an "Indian", the Province of Canada was able to proceed with the Gradual Civilization Act, 1857 [20] that offered voluntary enfranchisement to "Indians" that would remove the legal distinction between them and other Canadian subjects. Enfranchised "Indians" received ownership of a piece of land (50 acres or 20.2 hectares) from the reserve lands set apart for his "Band" (i.e., Indigenous group). A lump-sum payment of their share of Band annuities and revenues would also be procured if the applicant met specific criteria (e.g., male; $\geq 21$ years of age; speak, read, and write English or French) under this Act. However, the enfranchised "Indian" male and family could no longer partake in on-reserve activities. In effect, the Gradual Civilization Act [20] would assimilate male "Indians", and their families and descendants into mainstream Canadian society, and break apart a Band's reserve land into private property lots to be developed. The Province of Canada envisioned that the communal reserve system would eventually be dissolved through private property allotments [21,22]. Thus, legal assimilation would occur on two fronts: the voluntary surrender of "Indian" status by First Nations people, and the dissolution of First Nations' reserve lands through private property allotments. It was not until 1860 that the Province of Canada took over the legislative responsibility of the "Indians" and the administrative infrastructure from the British Government [18].

After confederation, the Dominion of Canada passed the Gradual Enfranchisement Act, 1869 [23] that reaffirmed the voluntary enfranchisement process of "Indian" males, and introduced the involuntary loss of "Indian" status when "Indian" women married non-Indian men. Furthermore, in reference to the payment of annuity money [23] (paragraph 4), an "Indian" was defined as "no person of less than one fourth Indian blood" with a certificate verifying this information from the respective Chief and Council, and sanctioned by the Dominion of Canada. These types of unilateral blood quanta definitions has been globally 
used as an assimilative tool by colonial governments [24-26]. In 1876, the Indian Act [27] consolidated and amended all pre-confederation legislation with respect to "Indians" in Canada into one legal document [18]. The consolidated Act did not change the parameters for the voluntary enfranchisement of "Indian" men or loss of "Indian" status by "Indian" women who marry non-Indian men. However, in 1920, involuntary enfranchisement for First Nations men who met certain criteria, such as having received a university degree and/or became a priest or minister, was introduced as an Indian Act amendment [28,29]. Although other enfranchisement initiatives followed the Indian Act [18], enfranchisement was a failed policy of assimilation $[17,21]$.

In 1969, the Statement of the Government of Canada on Indian Policy [30] was released and became known as the "White Paper". The White Paper called for the following: the repeal of the Indian Act in order to make First Nations people ordinary citizens of Canada without special rights and privileges; the elimination of the Department of Indian Affairs with provincial governments taking on the responsibility for First Nations people; and the dissolution of reserve lands through a fee simple system. The response to the White Paper came in the form of the Citizen Plus document, which became known as the "Red Paper" [31]. In the Red Paper, it was emphasized that First Nations people should be considered "Citizen Plus" as mentioned in the Hawthorn reports [32,33], that is, as charter members of Canada, First Nations people possessed certain additional rights compared to ordinary Canadians. To put this succinctly: "To preserve our culture it is necessary to preserve our ["Indian"] status, rights, lands and traditions." [31] (p. 194). In 1970, the White Paper was formally withdrawn [18].

In 1985, Bill C-31 [34] introduced amendments to the Indian Act, whereby women who lost their status by marrying non-status males could have their status restored, and their children eligible for registration as an "Indian" (i.e., gain status) [35]. Allowing for the fact that, between 1985 and 1999, approximately 174,500 individuals became registered, population projections showed that, after two generations, the status population would rapidly decrease and disappear at the end of the fifth generation [35]. Prior to Bill C-31, registered "Indian" (i.e., status on the Indian Register) and First Nations' (Band) membership were indistinguishable [36]. Since the implementation of Bill C-31, the Indian Register is only applicable where the First Nation has not adopted their own membership rules, and membership rules are varied (e.g., blood quantum, one parent, Indian Act equivalent) [36]. Additionally, Bill S-3 [37] was passed in 2017 to address other known gender-based inequities in the Indian Act (e.g., the 1951 cut-off), and modelling projections of people entitled to registration showed an initial increase in the status populations, followed by a decrease [38]. Under the present legal definition of a registered "Indian", the status population will disappear over time; it is not a matter of if, but a matter of when (see Table 1).

Table 1. An Abridged History of Legal Assimilation Benchmarks in Canada.

\begin{tabular}{cl}
\hline Date & \multicolumn{1}{c}{ Legal Assimilation Events } \\
\hline 1830 & Indian Civilization Agenda-ceding of land through treaties and establishing reserves. \\
\hline 1857 & $\begin{array}{l}\text { Gradual Civilization Act-opportunity to voluntarily remove Indian status from men } \\
\text { for benefits. }\end{array}$ \\
\hline 1869 & $\begin{array}{l}\text { Gradual Enfranchisement Act-reiteration of Gradual Civilization Act and involuntary } \\
\text { removal of Indian status from women who marry non-Indian men. }\end{array}$ \\
\hline 1876 & Indian Act-codification of the previous acts, including pre-confederation acts. \\
\hline 1920 & $\begin{array}{l}\text { Indian Act Amendment-involuntary enfranchisement of Indian men who met } \\
\text { requirements such as a university education and certain religious standing. }\end{array}$ \\
\hline 1969 & $\begin{array}{l}\text { White Paper-complete dissolution of Indian status and rights proposed by the } \\
\text { Government of Canada. }\end{array}$ \\
\hline
\end{tabular}


Table 1. Cont.

\begin{tabular}{ll}
\hline Date & \multicolumn{1}{c}{ Legal Assimilation Events } \\
\hline 1970 & White Paper withdrawn after First Nations Red Paper responses. \\
\hline 1985 & $\begin{array}{l}\text { Bill C-31-restoration of Indian status to women who married non-native men, and } \\
\text { their children. }\end{array}$ \\
\hline
\end{tabular}

\subsubsection{Cultural Assimilation}

Pre-confederation industrial schools where trades and farming were taught were established as part of an international colonial trend to separate Indigenous children from their parents, and helped to shape the Government of Canada's decision to establish a residential school system $[39,40]$. In 1920, residential schools became compulsory under an Indian Act amendment [39]. The use of the residential school system was a central element of the Canadian process of assimilation that removed children from their homes, communities, land, and culture $[39,40]$. The residential school system allowed for the colonial government to surround young children almost 24 hours per day with non-Indigenous culture through various media (e.g., printed, radio, television) and religion; utilizing Indigenous languages and maintaining other types of Indigenous identity (e.g., hair or dress) were strictly forbidden and severely punished $[39,40]$. Residential schools significantly disrupted families; prevented transmission of cultural values and identity [39,40]; and, when these residential schoolchildren became adults, many turned to unhealthy behaviours in order to cope with the chronic trauma of emotional, physical, and sexual abuses [41]. In spite of Indigenous cultures being severely impacted by residential schools, Indigenous cultures continue to survive $[39,40]$.

Following the failure of the residential-school initiative, an estimated 20,000 Indigenous children were removed from their homes, communities, and cultures by Canadian child welfare agencies during the period from the late 1950s to the early 1980s [42,43]. These children were adopted out into non-Indigenous homes, communities, and cultures sometimes outside of Canada, in what later became known as the Sixties Scoop [42,43]. This type of Indigenous removal system occurred in other countries, such as the USA, Australia, and New Zealand with the same end goal of the assimilation of Indigenous people into the dominant colonial society [44]. Recent quantitative studies found evidence of a link between being impacted during the Sixties Scoop and having a parent who attended residential school; this suggests intergenerational cycles of risk [41].

Although the government of Canada maintained aggressive assimilation polices over a prolonged period of time, Canadian Indigenous people maintained their identity and communities, and still assert their inherent and treaty rights [45]. Lastly, as stated by the Truth and Reconciliation Commission of Canada [40] (p. 205): "In Canada, law must cease to be a tool for the dispossession and dismantling of Aboriginal societies". Politicians and non-Indigenous Canadians must realize that many recent laws have assimilative elements that can appear to be democratic, but on closer inspection, these acts facilitate assimilative processes such as environmental assimilation.

\subsection{Northern Ontario, Canada, and the James Bay Treaty-Treaty No. 91905}

As detailed above, the Government of Canada was unsuccessful in their efforts to break apart and develop First Nations' reserves; thus, the government of Canada refocused and devoted its attention to development on Indigenous homelands external to reserve lands. When the Dominion of Canada was founded in 1867, the Province of Ontario (at the time Canada West) only consisted of the southern portion of present-day Ontario [46]. The landmass of present-day Ontario would be realized through legislation $[47,48]$ and the subsequent signing of treaties with "Indian" groups [49].

Since, the British Government recognized that "Indians" held land rights in North America through the Royal Proclamation of 1763 [50], the consent of the "Indian" groups for the surrender (i.e., ceded or purchased) of their lands was required. In 1889, Ontario's 
boundary was extended northwards [47], and development soon followed in forms such as railway construction and settlement. Thus, "Indian" title needed to be ceded; Macrea [51] (p. 1) of the Office of the Inspector of Indian Agencies and Reserves, Dominion of Canada, sent a memorandum with a map to the Superintendent-General of Indian Affairs, Canada outlining the land that needed to surrendered by the "Indians" (Figure 1). The Macrea [51] map (Figure 1) marked the beginning of formal discussions with respect to the boundaries of "Indian" land to be considered under Treaty No. 9 [52,53]. The Macrea [51] map (Figure 1) shows that the James Bay-Treaty No. 9 (Treaty No. 9) was originally to include "unceded" land north of the Height of Land in both northern Ontario and Quebec, south of the Albany River in Ontario, and south of the Nottaway River in Quebec [54]. However, the boundaries changed when Pedley [55] (pp. 5-7), Deputy Superintendent-General of Indian Affairs, specified:

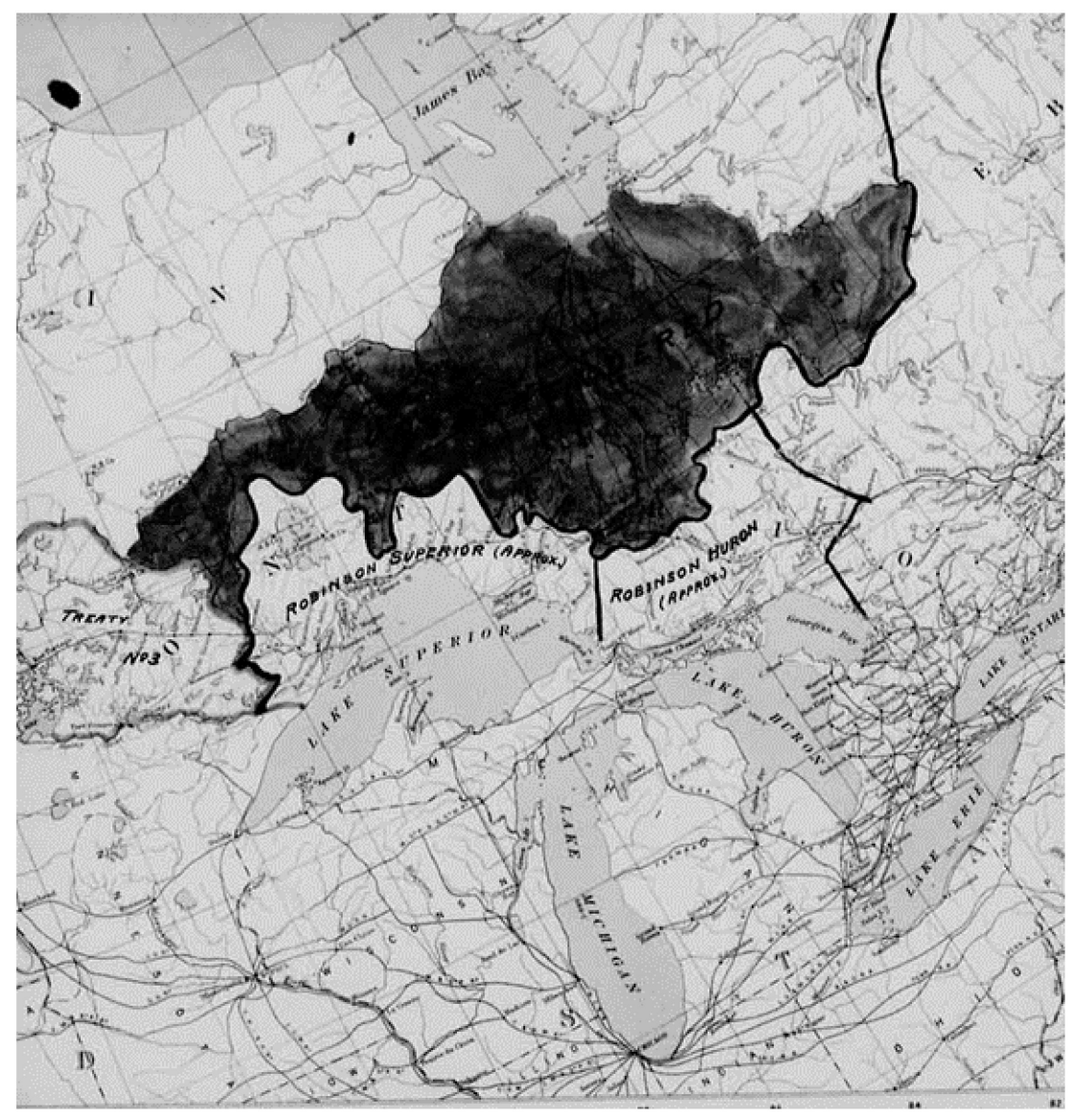

Figure 1. Macrae's [51] map showing land to be surrendered or ceded in the proposed treaty.

So far as the Indians of Quebec are concerned, it is suggested that no treaty should be made with them or that any Quebec Indians living temporarily in Ontario should be included in the Ontario treaty. (Treaty No. 9)

The final boundaries of Treaty No. 9 (Figure 2) were as follows:

the said Indians [Cree, Ojibwe, and Oji-Cree peoples] do hereby cede, release, surrender and yield up to the government of the Dominion of Canada, for His Majesty the King and His successors forever, all their rights titles and privileges whatsoever, to the lands included within the following limits, that is to say:That portion or tract of land lying and being in the province of Ontario, bounded on the south by the Height of Land and the northern boundaries of the territory ceded by the Robinson-Superior Treaty of 1850, and the Robinson-Huron Treaty of 1850, and bounded on the East and North by the boundaries of the said 
Province of Ontario as defined by law [added emphasis], and on the West by a part of the eastern boundary of the territory ceded by the Northwest Angle Treaty No. 3. [51] (pp. 19-20)

Note the sharp demarcation on the eastern border of Treaty No. 9 between Ontario and Quebec (Figure 2).

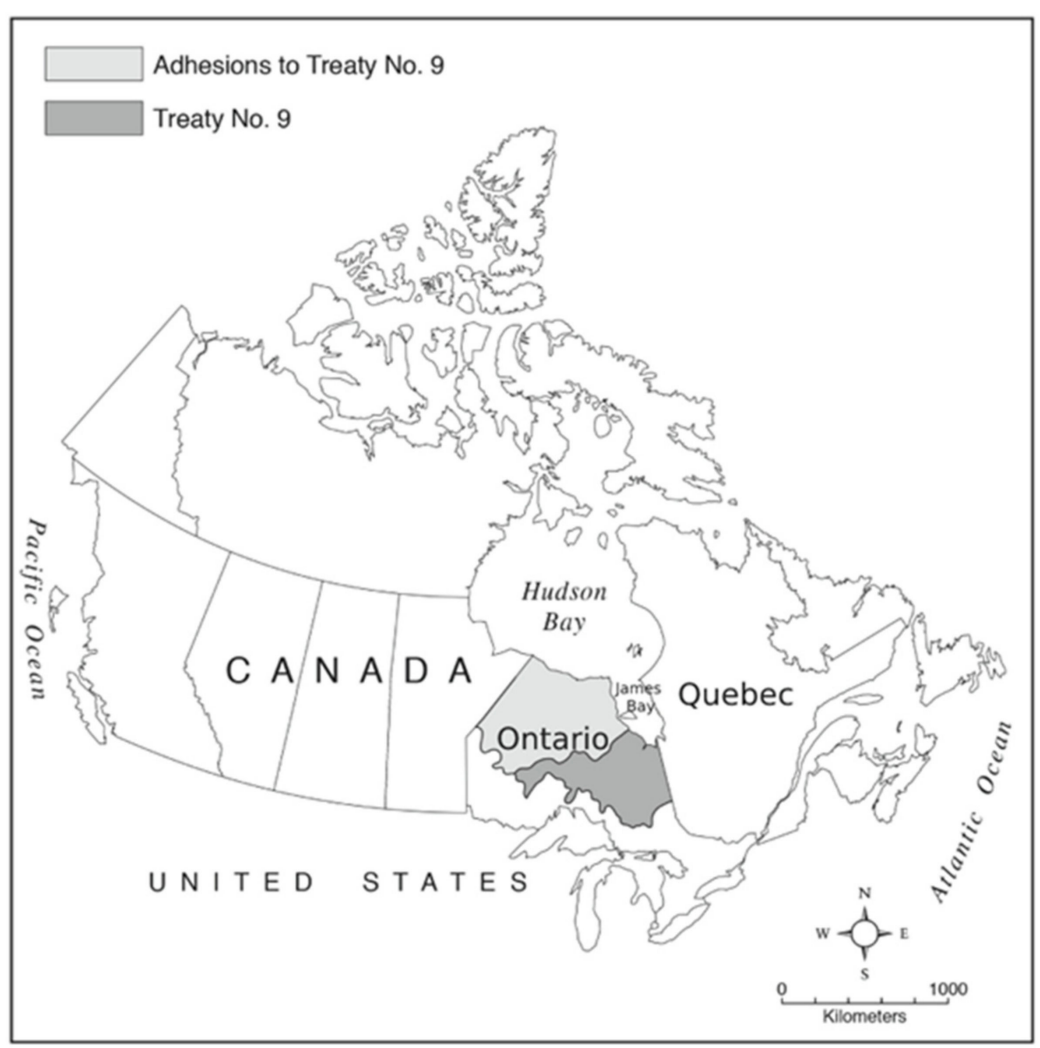

Figure 2. Map showing areas covered by Treaty No. 9 and its adhesions.

2.3. The Green Energy and Green Economy Act (2009), the Mining Amendment Act, 2009, the Far North Act, 2010, and the COVID-19 Economic Recovery Act, 2020

In 2008, the world was engulfed in the largest financial crisis since the Great Depression [56]. In this economic context, Ontario introduced the Green Energy and Green Economy Act, 2009 (also known as the Green Energy Act) [57], the Mining Amendment Act, 2009 [58], and the Far North Act, 2010 [59]. The Premier of the Government of Ontario, McGuinty [60] (pp. 5027-5028), purported that the Green Energy Act was "fundamentally about new jobs, it's about clean, green electricity and it's about fighting climate change". Additionally, Smitherman [61] (pp. 4951-4952), the Minister of Energy and Infrastructure, suggested that the Green Energy Act would make Ontario

North America's green energy leader ... making it easier to bring renewable energy projects to life [by streamlining the application and approval process and] ... would offer an attractive price for renewable power, including ... hydro ... and would not limit the size of projects ... Ontario would join the ranks of global green power leaders like Denmark, Germany and Spain.

The Green Energy Act started as Bill 150, an omnibus bill that, when enacted, affected 20 acts [62]. Omnibus bills can amend, repeal, and/or enact several acts that may be unrelated [63,64]. However, omnibus bills undergo only a single vote in the legislature being either accepted or rejected in its entirety [65]. Omnibus bills, because of their complexity and changes to multiple acts, are not conducive to the democratic process [66].

Meanwhile, the Mining Amendment Act [58] (p. i) made "numerous amendments to the Mining Act relating to prospecting land, staking mining claims, disputing claims, 
assessment work, surface rights owners, exploration work, diamond mine royalties and consultation with Aboriginal communities". Lastly, the Far North Act set out a joint community-based land-use planning process for the Far North region of Ontario (Figure 3), and unilaterally established a protected area of 225,000 $\mathrm{km}^{2}$. The Far North Act started as Bill 191, an omnibus bill, and impacted three acts when enacted. Thus, the government of Ontario hoped that green energy and a green economy [66], mining [67], and Ontario's Far North [68] would be the economic salvation for the province to see it through the economic downturn.

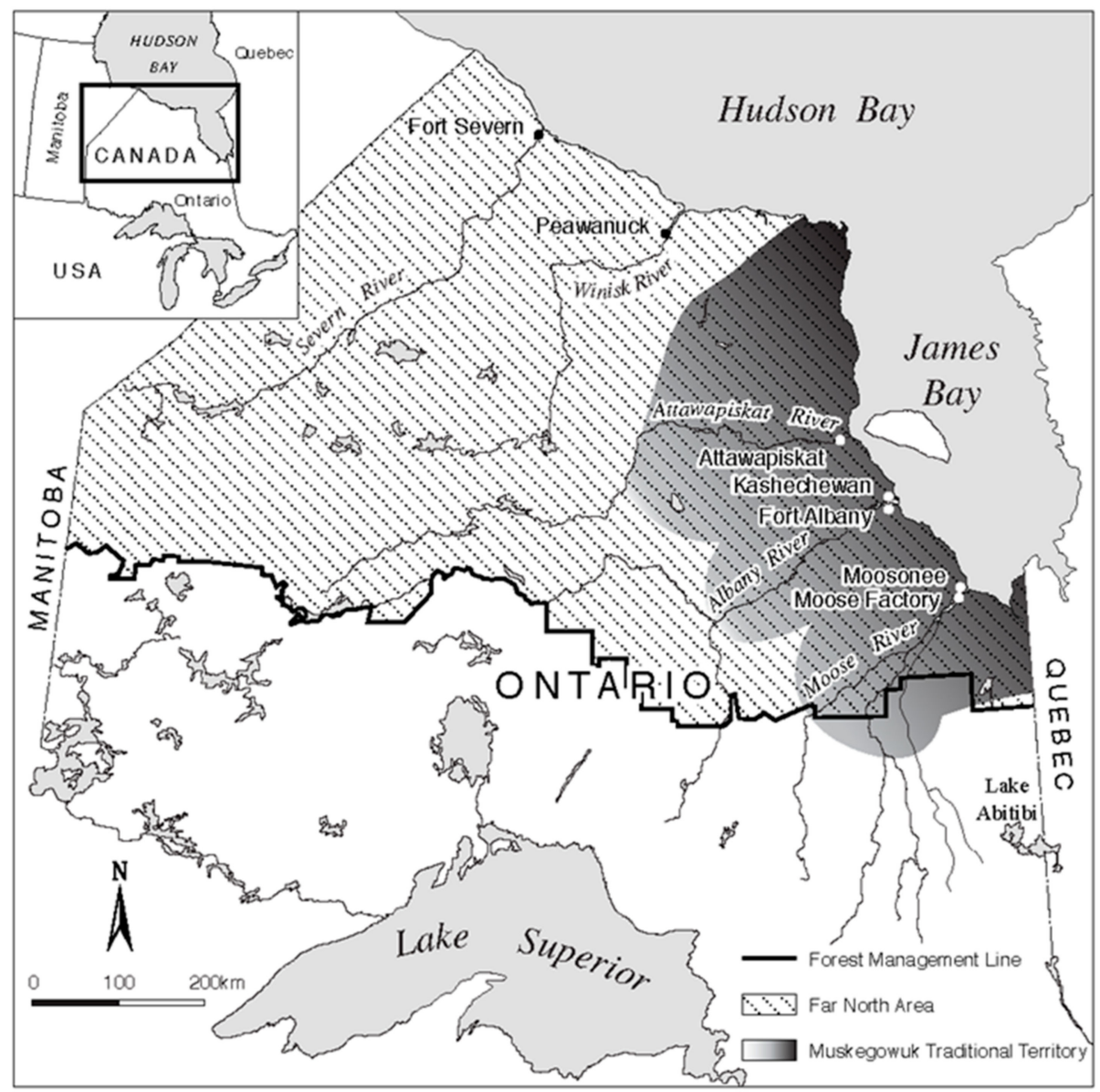

Figure 3. Map showing the demarcating line (i.e., forest management line) for the Far North region of Ontario, and the Ontario-Quebec boundary that passes through the eastern portion of Lake Abitibi.

In 2020, the emergence of COVID-19 [69,70] again plunged the world into an economic crisis. In Canada, everyone was impacted, but vulnerable Canadians, especially Indigenous peoples, were disproportionately impacted because of greater pre-existing vulnerabilities [71]. In May 2020, the government of Ontario implemented Phase 1 of Ontario's Action Plan in response to COVID-19, allocating CAD \$17 billion in targeted support [72]. In June 2020, Phase 2 of the economic restart for Ontario was initiated [72]. Phase 3 (the recovery phase) commenced in July 2020 [72], and the COVID-19 Economic Recovery Act [73] was introduced by the Government of Ontario, and was passed by the Legislative Assembly of Ontario. The COVID-19 Economic Recovery Act began as Bill 197, an omnibus bill that affected 43 acts when enacted.

\section{Methods}

\subsection{Geographical and Cultural Scope}

In Canada, the Province of Ontario contains more than 1 million $\mathrm{km}^{2}$ of land within its borders [74]. The economy of Ontario has been reported to be based on a mixture of 
sectors, such as natural resources, energy production, agriculture, manufacturing, financial services, and high-tech innovation [74]. Ontario has the largest Indigenous population of any province [75], with 133 First Nations [76] belonging to 13 distinct groups [75]. In northern Ontario, Nishnawbe Aski Nation has a membership of 49 First Nations with a land base of $543,898 \mathrm{~km}^{2}$ [77]. In the Far North region of Ontario (Figure 3), the Cree people occupy the northernmost area, the Oji-Cree inhabit the middle region, and south of the 50th parallel, the Ojibwas dominate [77].

\subsection{Data Collection and Analyses}

To gain a First Nations' perspective on land in northern Ontario, sustainable use, and development on their homelands, Standing Committee hearings for Bill 150 (Green Energy and Green Economy Act, 2009), Bill 173 (the Mining Amendment Act, 2009), Bill 191 (Far North Act, 2010), and Bill 197 (COVID-19 Economic Recovery Act, 2020) were accessed. Verbatim Hansard transcripts of Standing Committee public hearings constitute primary data and were read in their entirety. Standing Committee public hearing transcripts provided a window into how First Nations and their leadership viewed the land, sustainable use, development, and the issues in the bills under review. Primary data were collected for First Nations' leadership, and then manually coded using a deductive-framework approach on the basis of how First Nations' leadership viewed land, sustainable land use, and development. This activity was followed by inductive analysis, whereby themes emerged from the coded data themselves. For example, First Nations leadership data were first placed in the deductive-framework category of First Nations' relationships with the land in northern Ontario. Subsequently, through inductive analysis, the themes of the Importance of Land, The Land is Not Untouched, and Protection of the Land emerged from the data themselves. Data analyses were also iterative. Additionally, secondary data (e.g., environmental assessments and articles) provided further insight into First Nations perspectives on sustainable development.

To identify and evaluate passages of Treaty No. 9 in the context of environmental assimilation, a comprehensive in-person search, an online search at Library and Archives Canada, and an online search at the Archives of Ontario were conducted. Further, academic databases and online materials were accessed and evaluated. Lastly, Google Maps Imagery (C) was employed to visually identify examples illustrating environmental assimilation in relation to the Ontario-Quebec boundary of Treaty No. 9; the Ontario-Quebec boundary, as it passes through the eastern portion of Lake Abitibi, is of particular importance.

With respect to the Green Energy and Green Economy Act, the Mining Amendment $A c t$, and the Far North Act, the acts themselves, and the verbatim Hansard transcripts of Standing Committee public hearings and debates were examined in search of passages related to environmental assimilation. Similarly, select verbatim Hansard transcripts of the Legislative Assembly of Ontario debates for the Green Energy and Green Economy Act, the Mining Amendment Act, the Far North Act, and COVID-19 Economic Recovery Act were read to identify and evaluate passages in the context of environmental assimilation. Lastly, the acts were compared in the context of environmental assimilation.

\section{Results and Discussion}

4.1. A First Nations Perspective on the Environment in Northern Ontario, Sustainable Use of the Land, and Development on Their Homelands

When there are more than one viewpoint of the environment and sustainable land use, all ways of knowing should be considered to allow for a better understanding of complex issues, such as the development on First Nations' homelands [78,79]. The James Bay Moose Cree perspective of the environment:

comes from our [Cree] worldview as a people which make up one of many parts of our environment. This is intended to provide counterpoise to the western concept of the environment that is statistical and quantitative in nature and does not by itself adequately capture the spiritual, cultural and physiological connection 
of the Moose Cree people to nature and our deep rooted sense of reciprocity with the land, water and animals ... We believe that a western-scientific view of the environment is important, but equally valuable, is our unique way of perceiving, knowing and describing our environment. [79] (pp. 4-1-4-9).

This interconnectedness with the land was articulated by First Nations' leadership as follows: "We are one with the land" (Band Councilor Sam McKay of Kitchenuhmaykoosib Inninuwug First Nation [80] p. 912); “It's our lifeline, it's our bloodline of who we are" (Chief Jonathon Solomon of Kashechewan First Nation [81] p. 954); "We must care for the land as it has cared for us" (Moose Cree First Nation [79] pp. 4-3-4-9); and when people are displaced off the land "Their identity is lost." (Chief Andrew Solomon of Fort Albany First Nation [82] p. 953; see also Table 2). Additionally, First Nations' leadership emphasized that their homelands were not "an untouched land; it's not a land that has been discovered)." (Chief Jonathon Solomon of Kashechewan First Nation [81] p. 954; see also Table 2) To the point, Special Envoy Frank Beardy of Nishnawbe Aski Nation, a Tribal Council of 49 First Nations in northern Ontario [83] (p. 953) forcibly espoused:

We are the north. It is our land, and we govern and protect by our inherent right given to us by the Creator. We have protected and governed the lands for thousands of years. The legacy of our care is that our use has been next to invisible. To you, the lands look untouched. They aren't. They've just been touched by the Anishnawbe in accordance with Anishnawbe laws and customs. That's why the lands are in the condition they are in. We will continue to protect and govern the lands for future generations [added emphasis].

Thus, land stewardship was considered to be an inherent right bestowed upon First Nations by the Creator $[77,82]$. First Nations protection of the land meant: "to live in harmony with the land and preserve it, not destroy it [through resource development] in a few years. We [First Nations and the Government of Ontario] have two very different concepts of development" (Band Councillor Sam McKay of Kitchenuhmaykoosib Inninuwug First Nation [80] p. 912; see also Table 2).

Table 2. Indigenous relationships with the land as described by First Nation leaders of northern Ontario, Canada.

\begin{tabular}{ll}
\hline Themes & \multicolumn{1}{c}{ Representative Quotes } \\
\hline “Our concepts of preserving Mother Nature ... We are one with the land, we depend on it to \\
feed our families". (Band Councilor Sam McKay of Kitchenuhmaykoosib Inninuwug First \\
Nation [80] p. 912) \\
"We live in the north. The land up north is our home. It's our lifeline, it's our bloodline of who \\
we are ... Without land, we will [not] be Cree people of James Bay." (Chief Jonathon Solomon \\
of Kashechewan First Nation [81] p. 954) \\
"The protection of our homelands ... The far north is First Nations land ... the land looks after us. \\
We have an abundance of fish, wildlife, waterfowl and stuff, and as a result, the land is our social \\
welfare system, and we would like to keep it that way." (Chief George Hunter of Weenusk First \\
Nation [84] p. 956) \\
"We love our land and have a special, sacred attachment to it. Our philosophy is we believe that \\
we must care for the land as it has cared for us ... The land is the sacred resting places of our \\
ancestors and together, forms our collective cultural memory and oral history. Water is the \\
source of our life and is one of the most valued elements in our environment. Clean water \\
contributes to spiritual, mental and physical wellbeing. We've always been able to trust its \\
refreshment, nourishment and nutrients ... Our ancestors knew that clean air is also needed in a \\
healthy environment." (Moose Cree First Nation [79] p. 4-3-4-9) \\
"A lot of people are displaced [off the land]. The young people today don't know who they are. \\
Their identity is lost. So you have a high rate of suicide." (Chief Andrew Solomon of Fort Albany \\
First Nation [82] p. 953)
\end{tabular}


Table 2. Cont.

\begin{tabular}{|c|c|}
\hline Themes & Representative Quotes \\
\hline The Land is Not Untouched & $\begin{array}{l}\text { "The land up north is not an untouched land. Our people, my ancestors, travelled that land. All } \\
\text { over the area of my land, you can see sacred burial grounds ... So it's not an untouched land; it's } \\
\text { not a land that has been discovered. We've been there for thousands and thousands of years. We } \\
\text { were very nomadic people. We are still closely tied to the land ... Where there are footprints all } \\
\text { over the place in my territory, that signifies that my people were out in the land." (Chief Jonathon } \\
\text { Solomon of Kashechewan First Nation [81] p. 954) } \\
\text { "It is not an exaggeration to say we are the north. The pathways of that place are filled with our } \\
\text { stories and our history and are governed by our laws and customs. To this day, only First Nations } \\
\text { people live there." (Grand Chief Stan Beardy of Nishnawbe Aski Nation [77] p. 828) } \\
\text { "There is a story that was conveyed to me by a number of elders ... a story that reflects on the care } \\
\text { that we have given the land. They talked about the days when they used to move from area to area } \\
\text { within their lands and camped, using spruce boughs for bedding ... their task that was given to } \\
\text { them by their grandmothers to gather up the spruce boughs after, when they were breaking camp, } \\
\text { and make sure they were burned in one area, and that the land they had camped on ... would be } \\
\text { taken back to its natural form. That was how they looked after the land ... today, Ontario is } \\
\text { penalizing us because they're saying that that land is untouched by us." (Special Envoy Frank } \\
\text { Beardy of Nishnawbe Aski Nation [83] p. 953) } \\
\text { "A lot of people say it's our last frontier. What the government instead should be doing is } \\
\text { congratulating all of the First Nations and NAN territories for keeping the land in its natural } \\
\text { state: the way it is. We have not contaminated and harmed our land." (Chief George Hunter of } \\
\text { Weenusk First Nation [84] p. 956) }\end{array}$ \\
\hline Protection of the Land & $\begin{array}{l}\text { "We have thousands of years of intergenerational experience with how to live in harmony with } \\
\text { the land and preserve it, not destroy it [through resource development] in a few years. We have } \\
\text { two very different concepts of development." (Band Councillor Sam McKay of } \\
\text { Kitchenuhmaykoosib Inninuwug First Nation [80] p. 912) } \\
\text { "We protect our lands. They've been protected for thousands of years." (Chief David Babin of } \\
\text { Wahgoshig First Nation (formerly Abitibi-Ontario Band of Abitibi Indians) [85] p. 955) } \\
\text { "The far north, it's only First Nations people who live there. We have lived there for close to 10,000 } \\
\text { years and we have preserved the natural environment up until now. We will continue to protect } \\
\text { the natural environment." (Grand Chief Stan Beardy of Nishnawbe Aski Nation [77] p. 831) }\end{array}$ \\
\hline
\end{tabular}

Bold used for added emphasis.

Colonizers tend to view the land as a commodity, property, or resource, something to be owned and developed [6]. From this perspective, non-Indigenous Ontarians in general have long viewed northern Ontario as "an untouched land" (Table 2) full of resources ready to be settled, developed, and exploited. Although vast resources do exist in northern Ontario [68], northern Ontario is the homeland of over 49 First Nations who have lived there for millennia under Indigenous laws (Table 2) and codes of conduct [86-88]. The land only has the appearance of being untouched because First Nations have respected and sustainably utilized the land, and preserved it for future generations (Table 2).

Northern Ontarian First Nations are not against development, but development must be guided by sustainable practices (Table 3). If not, the consequences are severe and disproportionately shouldered by First Nations: "European people have come here, and look what they've developed; they've developed a land of disaster. They take all the revenues and whatever and leave, and leave us with nothing. Then we have to do the cleanup". (Chief David Babin of Wahgoshig First Nation (formerly Abitibi-Ontario Band of Abitibi Indians) [85] p. 955); and "you polluted everything; you polluted all south of 50 [parallel] ... and still you want more. You want to go north of 50 now". (Chief Keeter Corston of Chapleau Cree First Nation [89] pp. 955-956) (see also Table 3). 
Table 3. Sustainable land use in northern Ontario, Canada, an Indigenous perspective.

\begin{tabular}{cl}
\hline Themes & \multicolumn{1}{c}{ Representative Quotes } \\
\hline "European people have come here, and look what they've developed; they've developed a land \\
of disaster. They take all the revenues and whatever and leave, and leave us with nothing. Then \\
we have to do the cleanup . . Our people are getting sick from all these industries that are coming \\
around our territory." (Chief David Babin of Wahgoshig First Nation (formerly Abitibi-Ontario \\
Band of Abitibi Indians) [85] p. 955) \\
"You polluted everything; you polluted all south of 50. You cut every tree; you've ruined it. \\
Species are at risk ... and still you want more. You want to go north of 50 now; you want to go \\
north there because you've ruined it here ... I've warned the northern chiefs. I live south of the \\
50th parallel, and I've seen the behaviour. The behaviour hasn't changed one bit." (Chief Keeter \\
Corston of Chapleau Cree First Nation [89] p. 955-956)
\end{tabular}

"I feel that we've done a lot of work as First Nations in how we want to proceed with our territory and foresee how it's going to develop ... and yet you don't listen to us anyway." (Chief David Babin of Wahgoshig First Nation [85] p. 955)

"The bill requires 225,000 square kilometres. The First Nations' traditional territory is protected and off limits with respect to development. This was made without consultation with us or any First

Not against development Nation in the far north, and means that there will be instances when a First Nation wishes to support development on their land but is barred from doing so due to it being protected land." (Chief Theresa Hall of Attawapiskat First Nation [90] p. 982)

"We are not against development. All we're saying is, we continue to live in poverty while the province gets wealthier and richer." (Chief Jonathon Solomon of Kashechewan First Nation [81] p. 954)

"The reality is, many of us are actually coming at this from a totally different perspective-it's like we're speaking two different languages-on the indigenous viewpoint on development and how we should be seeing the future." (Chief Randy Kapashesit of the MoCreebec Council of the Cree Nation [91] p. 957)

"When we talk about protected areas, there are two perceptions to that. Our definition of protected areas means saving something for future uses. Under the provincial legislation, when we talk about protection, we're talking about preventing any activity from that protected

Sustainable development area forever and ever and ever." (Grand Chief Stan Beardy of Nishnawbe Aski Nation [77] p. 831) "You're [Government of Ontario] only thinking about what's happening today. We've got to think about tomorrow. We've got to think about our kids, our children who are coming. What are we going to leave them? Are they going to live on nothing...the hydro dams and the damage they've done. They washed away our graveyards into the lakes, and yet development still happens ... You took us off our land. You took us away from our home so you can develop industry ... The point is what? Destroying the lands, our rivers, our waters? (Chief David Babin of Wahgoshig First Nation [85] p. 955)

Bold used for added emphasis.

Lastly, from a First Nations' worldview, First Nations have not and do not own their homelands; thus, First Nations could not have "ceded" their homelands through the signing of Treaty No. 9. The act of "surrendering land was a totally foreign concept" for the Cree and Ojibway of northern Ontario [92]. Nonetheless, sharing is foundational to Cree culture $[86,93]$, and this is why the Cree contend that they only agreed to share the land by signing Treaty No. 9 [94,95], but their reserve land was solely for First Nations use [96]. Thus, there is the question of unceded land with respect to Treaty No. 9 and the oral promises made by Treaty No. 9 commissioners [97]. In addition, from a common-law perspective, the question of unceded land in northern Ontario extends to the Treaty No. 9 package itself [98], Treaty No. 9 adhesions [99] and emergent land [53,100], and the islands of the western James Bay region [101-104].

\subsection{Treaty No. 9}

Treaty No. 9 and its adhesions were unique among numbered treaties signed from 1870 to 1930 with First Nations groups [49] because one of the treaty commissioners represented the Government of Ontario [105]. The Dominion of Canada had to make this accommodation after Ontario won the St. Catherine's Milling decision. After 1894, Canada 
was required by law to obtain the concurrence of the government of Ontario for any treaties related to Indian lands in Ontario [106].

\subsection{1. "Taken-Up Clause"}

In Treaty No. 9, a specific passage became known as the "Taken-up Clause":

And His Majesty the King hereby agrees with the said Indians that they shall have the right to pursue their usual vocations of hunting, trapping and fishing throughout the tract surrendered as heretofore described, subject to such regulations as may from time to time be made by the government of the country, acting under the authority of His Majesty, and saving and excepting such tracts as may be required or taken up from time to time for settlement, mining, lumbering, trading or other purposes [added emphasis]. [51] (p. 20).

When Treaty No. 9 was signed, the First Nations signatories could not read, write, or speak English, so translators were used to interpret the treaty text [97]. Remarkably little was explained to Treaty No. 9 signatories about future land use in the Treaty No. 9 region [107], and no evidence exists that the taken-up clause had been explained to the Treaty No. 9 signatories [94,97]. Evidence in existence from the Treaty No. 9 commissioner journals [108,109] and Cree oral history indicated that the First Nations people were promised the indefinite continuation of hunting, trapping, and fishing activities wherever they wanted $[94,97]$. At no time was it mentioned that the Province of Ontario would administer the "surrendered" land, and introduce game and fish laws restricting harvesting activities [107]. There was a complete disconnect between the written text of Treaty No. 9 and what was promised to the signatories through the commissioners' oral promises [94,97]. Furthermore, waterpower-generation stipulations were included in the concurrence agreement between Canada and Ontario, unbeknownst to the First Nations signatories of Treaty No. 9; the agreement was supposed to have been attached and been part of the Treaty No. 9 package, but it was not [98].

In 1905, when Treaty No. 9 was signed, the First Nations people of northern Ontario were not enfranchised. Thus, they had no right to vote and would never be represented by the Government of Canada or Ontario until enfranchised. Without a voice in government at either the provincial or federal level, the First Nations people had no say with respect to development in their homelands. Although treaty rights to hunt, fish, and trap became entrenched when the Canadian Constitution Act, 1982 was repatriated, the government of the country could override these rights and develop in the First Nations homeland if in the best interest of the people the government represented, that is, the non-Indigenous majority [68].

\subsubsection{First Nations People of the Lake Abitibi Region and Environmental Assimilation}

In 1905, the Hudson's Bay Company post on Lake Abitibi was the last to be visited; this post was located at the eastern end of Lake Abitibi in Quebec [97,110]. Due to the Treaty No. 9 Commission arriving late in the season, few First Nations' people were at the Abitibi post to sign the treaty [111]; thus, Treaty No. 9 was not signed by the Abitibi First Nations people until 1906, and only those with lands in Ontario signed the treaty [111]. The 1908 Adhesion brought the Abitibi-Quebec First Nations people into Treaty No. 9 whereby they shared the Ontario-Abitibi reserve with the people who signed in 1906 [97]. This awkward situation arose because the Ontario-Quebec border was an imaginary line not based on First Nations boundaries; the north-south Ontario-Quebec boundary cut Lake Abitibi into two sections. Additionally, First Nations peoples' land title was historically recognized by the British in Ontario (formerly Canada West), but not by the French in Quebec (formerly Canada East) prior to confederation [111]. It was not until the 1970s when the Province of Quebec lost a land-title court case to the Quebec James Bay Cree that the Lake Abitibi region of northern Quebec would be covered by treaty [112]; the resulting James Bay and Northern Quebec Agreement [113] was the first of the modern Canadian treaties. 
The result of approximately 70 years of unfettered development on the Quebec side of the Lake Abitibi can be seen in Figure 4. The Ontario-Quebec border that cuts through Lake Abitibi shows widespread areas of environmental assimilation on the Quebec side of the border, where there is a concentration of agricultural land and other types of development, and relatively little development on the Ontario side of the border near the demarcating line (Figure 5). However, the northern Ontario area around Lake Abitibi covered by Treaty No. 9 was also developed (Figure 6), but environmental assimilation was not as extensive compared to northern Quebec, where there was no treaty until 1975 [113] (Figures 4 and 5). For example, as the Abitibi River flows westward from Lake Abitibi towards Iroquois Falls, there is hydroelectric development (Figure 6); the associated dams caused water levels to rise on Lake Abitibi with flooding in 1914-1915, and the displacement of First Nations people living around the lake [114]. The consequences of hydropower generation were unevenly experienced. Urban residents and industry reaped the benefits, while rural dwellers and First Nations people living near the hydrodevelopments suffered the burdens of development "in the name of the wider public interest" [115] (p. 4). Other industrial development (e.g., a pulp and paper mills, mining, transportation corridors) and agricultural activities in northeastern Ontario in the Lake Abitibi region [114] can be seen encircling Wahgoshig First Nation, albeit with a relatively large buffer region (Figure 6).

As a comparison, further along the environmental-assimilation spectrum is the area surrounding the Aamjiwnaang First Nation in southern Ontario (Figure 7). The Aamjiwnaang First Nation is an Ojibway community located along the St. Clair River with over 50 industrial facilities within a $25 \mathrm{~km}$ radius around the Aamjiwnaang First Nation [116] (p. 2). Essentially, the First Nation community is an Indigenous island in a sea of non-Indigenous development.
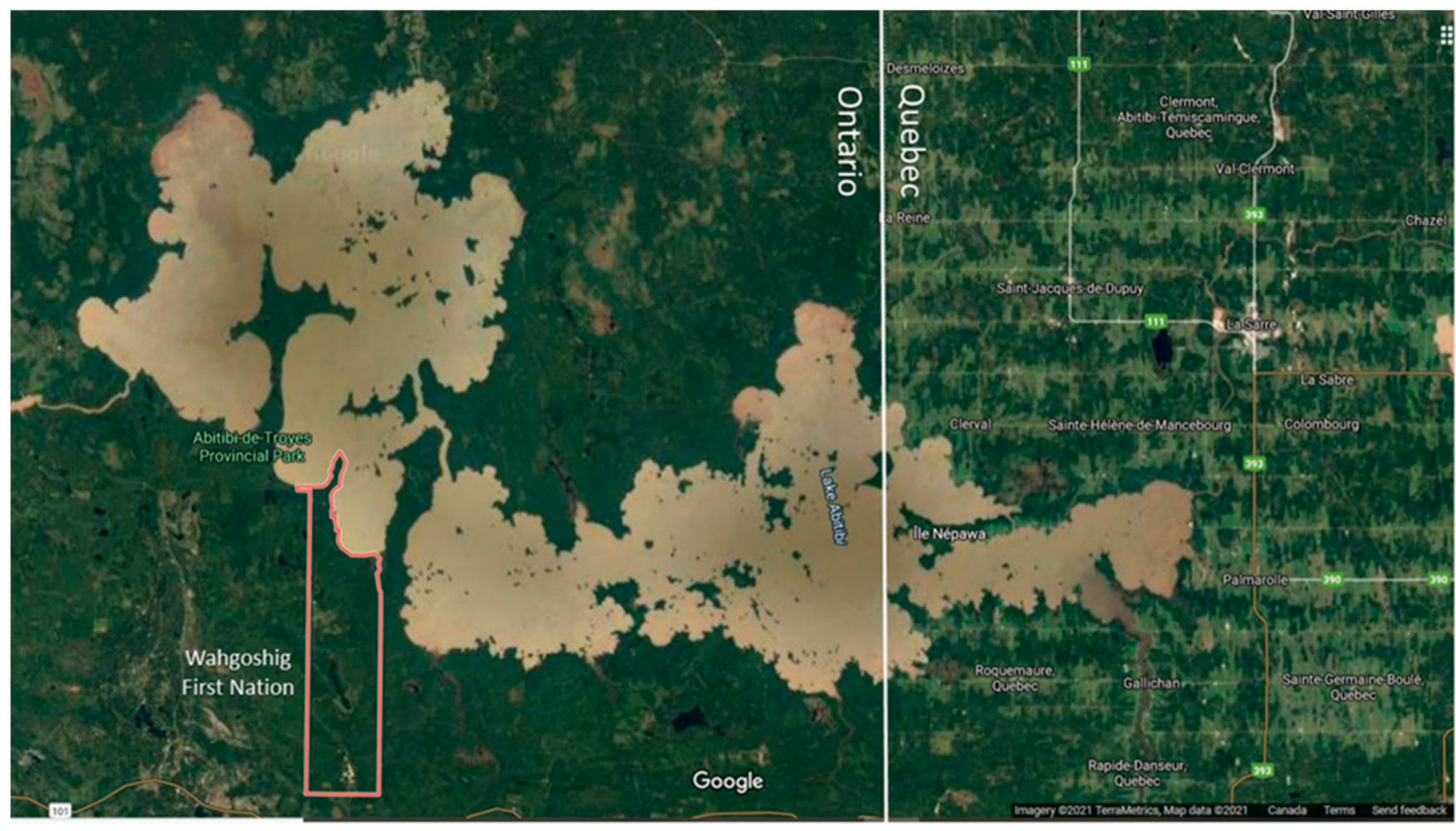

Figure 4. Ontario-Quebec border cutting through Lake Abitibi and extensive development on Quebec side of the border (Google Maps Imagery@ 2021; TerraMetrics Map data® 2021). 

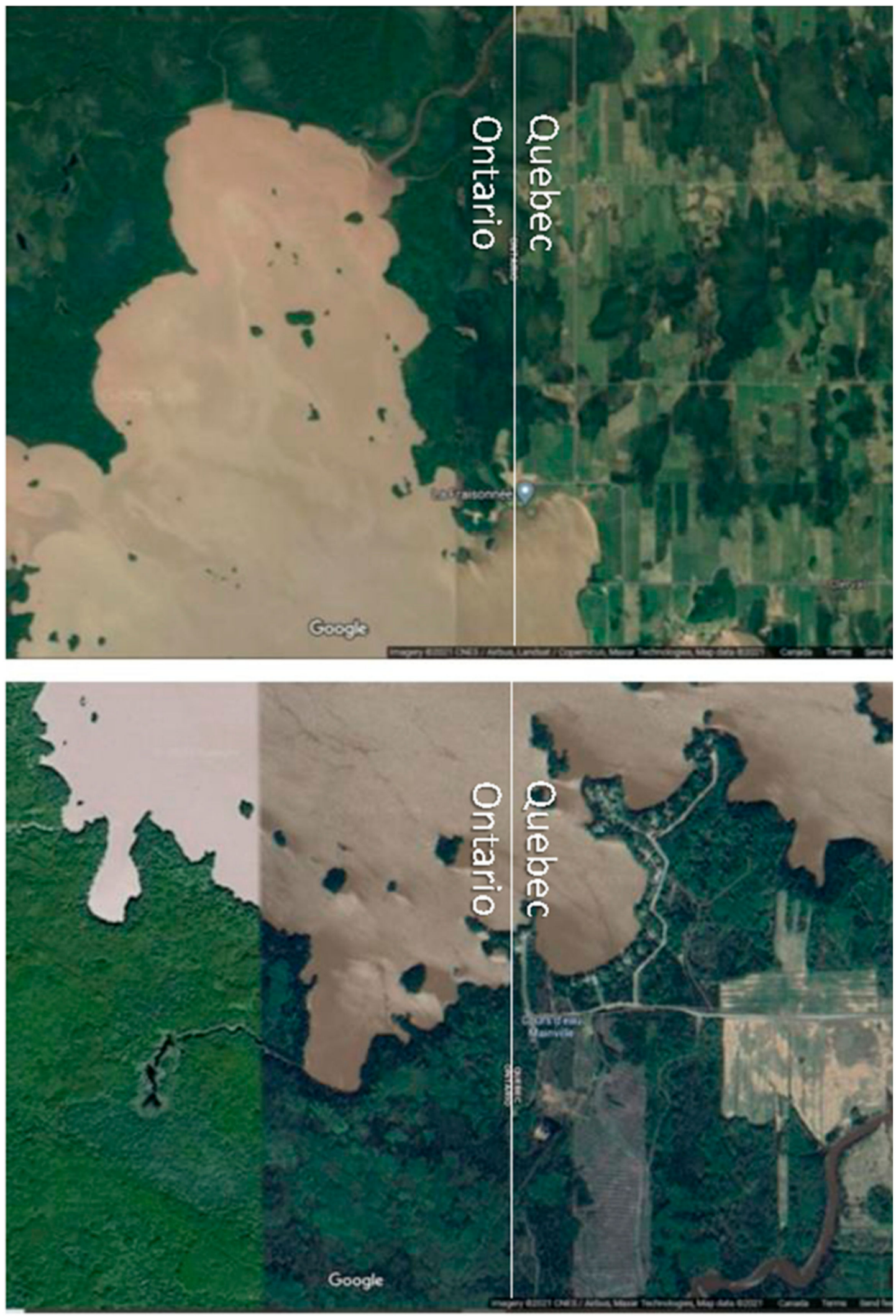

Figure 5. Close-up view of extensive development on Quebec side of the border of Lake Abitibi (top frame from Google Maps Imagery $\odot 2021$ CNES/Airbus Landsat/Copernicus, Maxar Technologies, Map data@ 2021; bottom frame from Google Maps Imagery @ 2021 CNES/Airbus, Maxar Technologies, Map data@ 2021). 


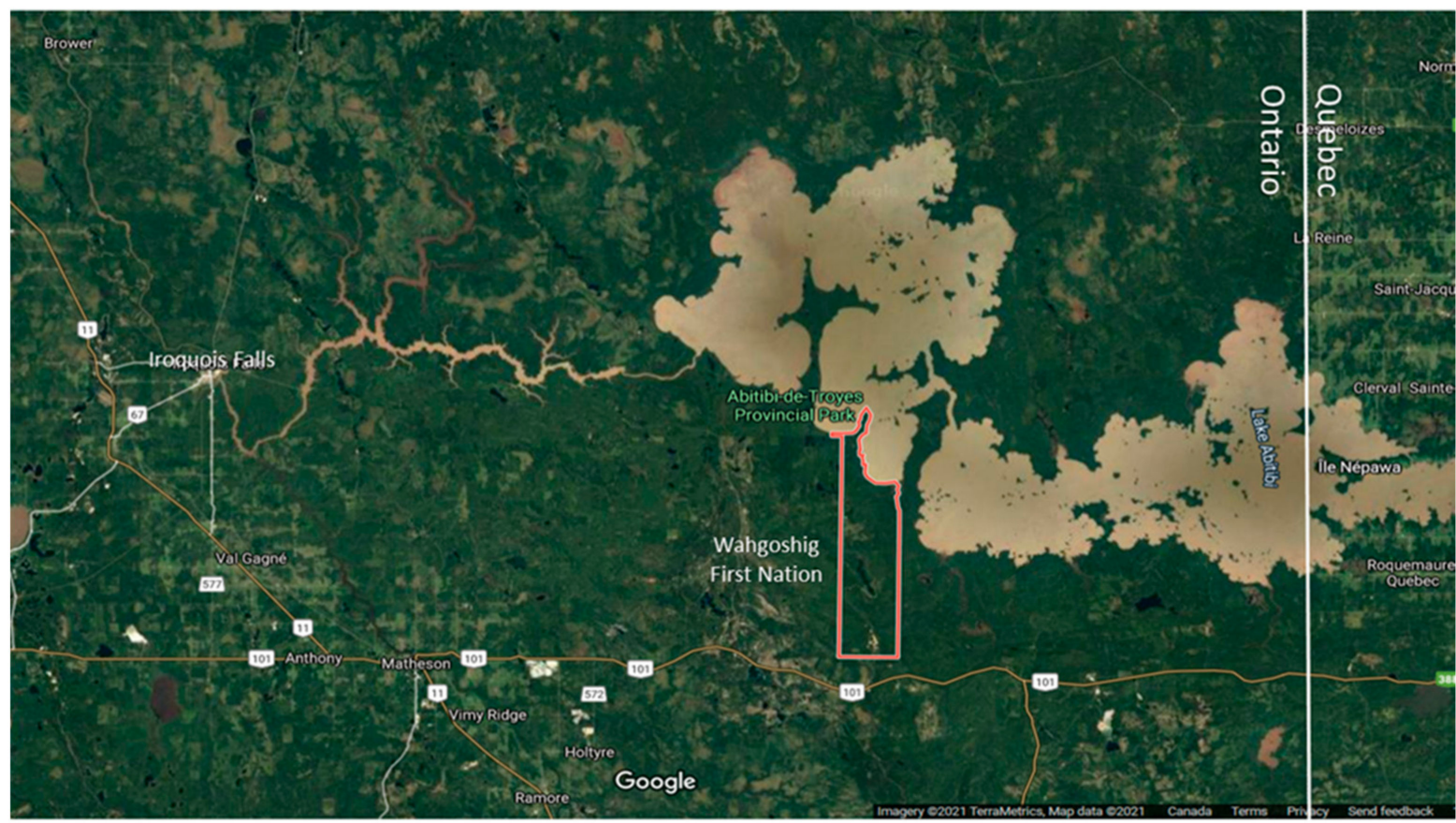

Figure 6. How development started to surround Wahgoshig First Nation in the Lake Abitibi of northern Ontario (Google Maps Imagery@ 2021 TerraMetrics Map data@ 2021).

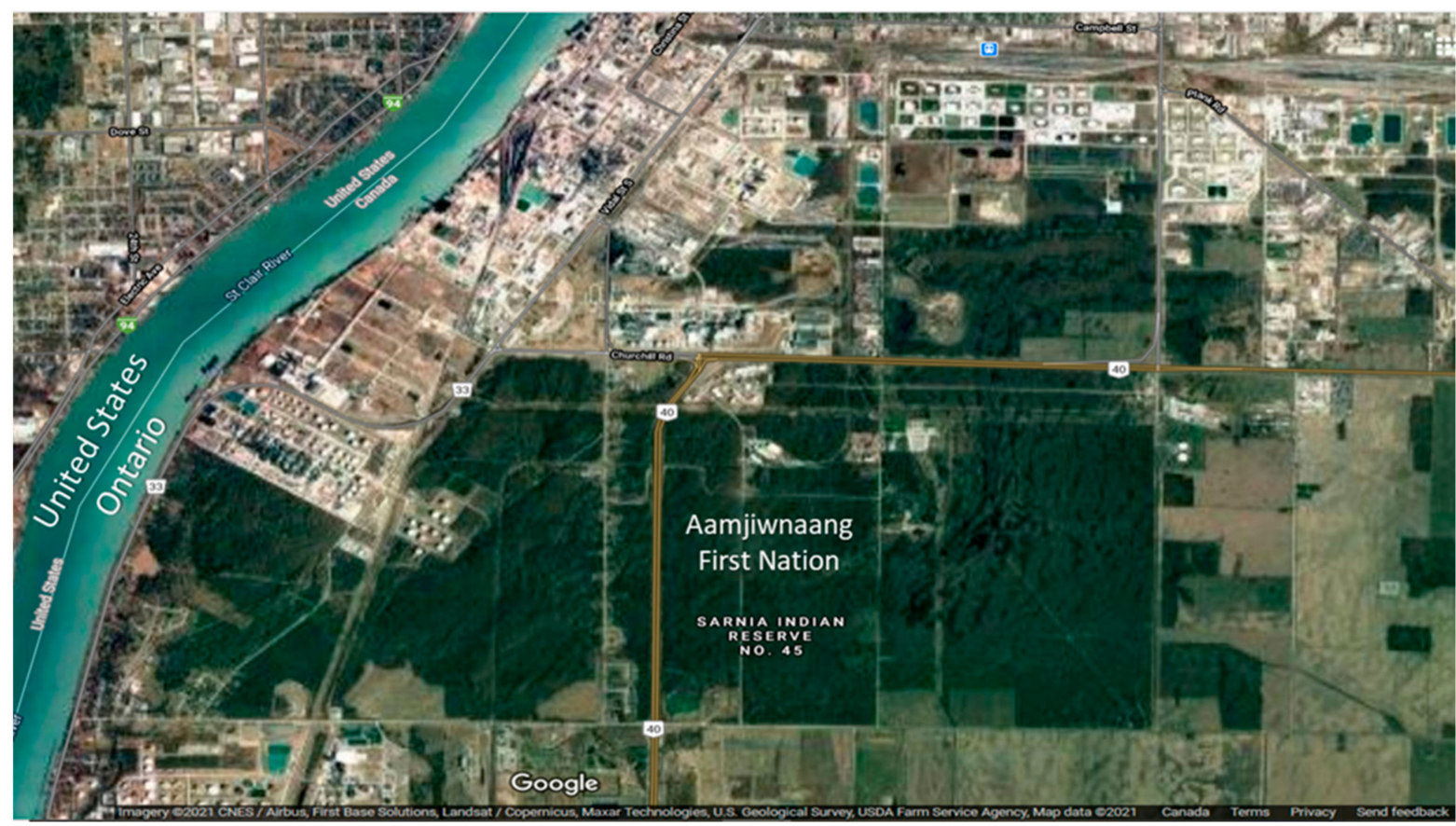

Figure 7. How development has fully surrounded Aamjiwnaang First Nation and abuts along its boundaries in southern Ontario (Google Maps Imagery @ 2021 CNES/Airbus, First Base Solutions, Landsat/Copernicus, Maxar Technologies, U.S. Geological Survey, USDA Farm Service Agency Map data@ 2021).

4.3. The Green Energy and Green Economy Act, 2009, the Mining Amendment Act, 2009, and the Far North Act, 2010

In Canada, the Indigenous population was estimated at 1673,785 , this being approximately $4.3 \%$ of the total Canadian population $[117,118]$. Even though the Indigenous population in Canada is growing at a record pace $(19.5 \%$ compared to a $4.2 \%$ increase 
for the non-Indigenous Canadian population) [117], immigration to Canada [119] keeps the Indigenous population around the $4 \%$ level of the total Canadian population for the foreseeable future. In Ontario, the 374,395 Indigenous people make up 2.8\% of the total population of the Province of Ontario, with the majority of Indigenous people living in small rural and remote population centres [118] located in northern Ontario [120]. Thus, it can be assumed that Indigenous people will never be in a majority and be considered the general public with respect to the Canadian or Ontarian population. This is especially true considering the population considered to be "Indian" status by the Canadian legal definition has been projected to decrease in future generations $[35,36,38]$. This is notable because three important documents relevant to development in northern Ontario, namely, the Green Energy and Green Economy Act, the Mining Amendment Act, and the Far North Act, all contain clauses that override First Nations inherent and treaty rights if deemed in the best interests of the general public. To the point, these pieces of legislation represent an unrecognized form of ongoing colonialism, as the acts enable environmental assimilation through development on First Nations homelands without meaningful input and/or their consent.

\subsubsection{The Green Energy and Green Economy Act}

Although green energy was never defined in the Green Energy Act [121], renewable energy was defined to include: "wind, water [added emphasis], biomass, biogas, biofuel, solar energy, geothermal energy, tidal forces and such other energy sources" (Schedule A, Part 1(1)). Furthermore, in the deliberations of the Legislative Assembly of Ontario, renewable energy was described as being the same as green energy [122]. Thus, when the Minister of Energy and Infrastructure, through the Green Energy and Green Economy Act, was given extensive powers to expedite green-energy projects by removing or modifying other existing pieces of legislation, the approval process for hydroelectric-power generation was streamlined or eliminated. The responsible section of the Green Energy and Green Economy Act is presented below:

5. (1) The Lieutenant Governor in Council [i.e., the Lieutenant Governor General, the Premier, and the Ministers of the Government of Ontario] may, by regulation, designate renewable energy projects [added emphasis], renewable energy sources or renewable energy testing projects for the following purposes:

1. To assist in the removal of barriers to and to promote opportunities for the use of renewable energy sources.

2. To promote access to transmission systems and distribution systems for proponents of renewable energy projects.

\section{Effect of designation}

(2) A person is permitted to engage in activities with respect to a designated renewable energy project, a designated renewable energy source or a designated renewable energy testing project in such circumstances as may be prescribed, despite any restriction imposed at law that would otherwise prevent or restrict the activity [added emphasis], including a restriction established by a municipal by-law, a condominium by-law, an encumbrance on real property or an agreement.

\section{Same}

(3) A restriction imposed at law that would otherwise prevent or restrict an activity with respect to a designated renewable energy project, a designated renewable energy source or a designated renewable energy testing project is inoperative to the extent that it would otherwise prevent or restrict the activity. (Schedule A, Part II, Subsection 51-3)

The section allowing for the unilateral streamlining or exempting of green-energy projects, especially hydroelectric-power generation projects, should have been amended during legislative deliberations; but with a Liberal majority government, Bill 150 rapidly progressed from bill to act in less than three months. Hydroelectric-power generation has 
severe negative effects on the environment at a local/regional level; these negative impacts on Indigenous communities have been well-documented in Ontario and globally. One of the environmental-justice issues with this act relates to the disproportionate burden that northern Ontario First Nations people would bear with respect to the costs, with little of the benefits, because most hydroelectric generation potential exists in the First Nations' homelands of northern Ontario. Indeed, McRoberts et al. [123] (p. 91) stated that the Green Energy and Green Economy Act was "an example of a failure by government to opt for a consensus-based decision making model ... the province's centralised, top-down financing, development and approval processes ... perpetuating environmental, social and procedural injustices".

Other sections of the Green Energy and Economy Act use the phrase "in the public interest" (Table 4), a priori justifying Government of Ontario actions. This type of legislation leads to (or allows for) environmental assimilation. Even when the Green Energy Repeal Act, 2018 [123] came into force in January 2019 [124], it amended other acts and used the phrase "systems necessary to the public interest" (Table 4). Discussion has already begun in the Legislative Assembly of Ontario about a green economic recovery from COVID-19:

there's a growing global consensus that now is the time for a green economic recovery from COVID-19 ... If you listen to the experts and the economists, they are saying that we need to align our COVID-19 recovery with climate action. This is a chance to build back better-to flatten the curve on climate pollution like we're working so hard to flatten the curve on COVID-19 [added emphasis]. [125] (p. 8927).

Lastly, although green energy has been reported as a clean source of energy by many non-Indigenous people [126] (p. 796), Indigenous peoples labelled the green economy as a "false solution" with respect to mitigation strategies [6] (p. 36).

Table 4. Other sections of Ontario's acts illustrating the unilateral power given to ministers and directors of the Government of Ontario if in the public interest.

\section{Act}

Green Energy Act, 2009 [56]
Representative Quotes

"SCHEDULE D ONTARIO ENERGY BOARD ACT, 1998

16. Subsection 96 (2) of the Act is repealed and the following substituted:

Applications under s. 92

(2) In an application under section 92, the Board shall only consider the following when, under subsection (1), it considers whether the construction, expansion or reinforcement of the electricity transmission line or electricity distribution line, or the making of the interconnection, is in the public interest:

SCHEDULE G ENVIRONMENTAL PROTECTION ACT

PART V.0.1 RENEWABLE ENERGY

Director's powers

47.5 (1) After considering an application for the issue or renewal of a renewable energy approval, the Director may, if in his or her opinion it is in the public interest to do so,

(a) issue or renew a renewable energy approval; or

(b) refuse to issue or renew a renewable energy approval.

Terms and conditions

(2) In issuing or renewing a renewable energy approval, the Director may impose terms and conditions if in his or her opinion it is in the public interest to do so.

Other powers

(3) On application or on his or her own initiative, the Director may, if in his or her opinion it is in the public interest to do so,

(a) alter the terms and conditions of a renewable energy approval after it is issued;

(b) impose new terms and conditions on a renewable energy approval; or

(c) suspend or revoke a renewable energy approval." 
Table 4. Cont.

\begin{tabular}{cl}
\hline Act & \multicolumn{1}{c}{ Representative Quotes } \\
\hline & "AMENDMENTS TO OTHER ACTS Niagara Escarpment Planning and Development Act \\
& Definition of utility \\
& (2.1) On the day section 6 of the Green Energy Repeal Act, 2018 comes into force, the definition \\
of "utility" in Appendix 2 of the Niagara Escarpment Plan is revoked and the \\
following substituted:
\end{tabular}

"SCHEDULE 6 ENVIRONMENTAL ASSESSMENT ACT

PART 11.3 COMPREHENSIVE ENVIRONMENTAL ASSESSMENTS

Terms of reference

17.4 (1) The proponent shall give the Ministry proposed terms of reference governing the preparation of an environmental assessment for the Part II.3 project ...

Approval

(10) The Minister shall approve the proposed terms of reference, with any amendments that he or she considers necessary, if he or she is satisfied that an environmental assessment

COVID-19 Economic Recovery Act, 2020 [73] prepared in accordance with the approved terms of reference will be consistent with the purpose of this Act and the public interest.

Same

(11) The amendments made by the Minister under subsection (10) may include amendments to impose requirements that are greater than or less than the requirements of the regulations if the Minister is of the opinion that in the circumstances, the amendments are necessary in order to ensure that an environmental assessment prepared in accordance with the approved terms of reference will be consistent with the purpose of this Act and the public interest."

Bold used for added emphasis.

\subsubsection{The Mining Amendment Act}

Similarly, in the Mining Amendment Act, it is specified that the Government of Ontario could override the terms of the legislation if it is for the greater good of Ontario:

No new mines (2) No new mine opening shall occur in the Far North if, (a) there is no community based land use plan for the area where the project is located; or (b) there is a community based land use plan but the land use designated for the area where the project is located is inconsistent with the opening of a new mine. Exception (3) Despite subsection (2), the Lieutenant Governor in Council may, taking into account any prescribed land use planning objectives, permit a new mine opening for a project described in that subsection if the project is in the social and economic interests of Ontario [added emphasis]. [57] (Part XIV Far North, 204).

Thus, First Nations interests could be overridden if the Government of Ontario deemed it was in the best interests of the non-Indigenous Ontario majority. First Nations leadership "went in the tent, so to speak, with the government officials to work on the changes that we would like to see that reflect on the concerns and issues of our people" [83] (p. 960). However, Chief Arthur Moore of the Constance Lake First Nation [127], speaking on behalf of the Matawa First Nations Tribal Council (nine First Nations located in northern Ontario), stated that most of the First Nations' recommendations were not included in the Mining Amendment Act. The process, whereby the Government of Ontario invited the First Nations into discussions but did not listen to the First Nations people, also occurred with the land-use planning legislation, the Far North Act [83]. 


\subsubsection{The Far North Act}

Originally, the land-use planning initiative was First Nations-led, but ended up being controlled by the Ontario Ministry of Natural Resources:

In Bill 191 [the Far North Act], Ontario holds all the cards, makes all the important decisions, sets out all the rules and tries to placate First Nations with the illusion of participation and control. (Special Envoy Frank Beardy of Nishnawbe Aski Nation [83] p. 952)

Specifically in the Far North Act [58] (Section 12, Development if no community land use plan):

\section{Exempting order}

(4) A person may undertake a development described in subsection (1) [e.g., opening a mine, commercial logging, oil and gas exploration, construction expansion of electrical generation facilities including hydroelectric power and associated infrastructure] if the Lieutenant Governor in Council, after taking into account the objectives set out in section 5 , by order determines that the development is in the social and economic interests of Ontario [added emphasis].

Likewise, in Section 14, Development if community land use plan, of the Far North Act:

\section{Exception, order}

(4) Subsection (1) or (2) does not apply if the Lieutenant Governor in Council, after taking into account the objectives set out in section 5 , by order determines that the allocation, disposition or use of public land and natural resources in the planning area or the development in the planning area, as the case may be, is in the social and economic interests of Ontario. [my emphasis] [58]

This overriding stipulation with respect to First Nations-based land-use plans did not go unnoticed by First Nations' leadership:

Also, the government has the ultimate power, with the explicit discretion under the bill, to override any land use plan and permits a new mine to be developed if it is in the economic and social interest of the province to do so. I take this as an insult. This is essentially saying that my community could prepare a land use plan, identify an area of land which, for whatever reason-whether cultural, traditional or environmental—is off limits for mining development and the government has the authority to basically say that there are economic and social interests of the province which are more important than my community's interest and proceed to permit the mine. [added emphasis]

—Chief Theresa Hall of Attawapiskat First Nation [90] (p. 982).

The Government of Ontario imposed their will on the First Nations people though legislation, all in the name of the non-Indigenous majority, and were soundly criticized by First Nations leadership. For example:

the Far North Act ... telling us that this is the way it has to be. "Never mind your human rights, never mind your historical rights; we're not interested in that": That's what you're saying by producing this kind of document and expecting us to participate (Chief Randy Kapashesit of the MoCreebec Council of the Cree Nation [91] p. 957)

Bill 191 is a fundamental threat to Whitewater Lake First Nation and other NAN First Nations. In brief summary, it does two things. First, it gives Ontario control of land use planning in the far north area. Second, it imposes an interconnected protected area of a super-park of at least 225,000 square kilometres ... This will ensure that NAN First Nations will remain part of the Third World forever [added emphasis]. (Chief Arlene Slipperjack of Whitewater Lake First Nation [128] pp. 948-949) 
The Government of Ontario's idea of land-use planning is one extreme or the other, that is, highly developed or fully protected. The First Nations' viewpoint of land-use stewardship is very different: the land can be utilized but should ideally appear untouched (Tables 2 and 3).

In 2019, a proposal was put forward by the Government of Ontario to repeal the Far North Act; however, after feedback, rather than repeal the act, it was proposed to amend it to better encourage economic development and collaboration with Far North First Nations with respect to land-use planning [129]. Public consultation for the proposed amendments to the Far North Act, 2010 ended on 14 January 2021 [130]. To refocus the act, the proposed amendments included the removal of the reference to the protection of $225,000 \mathrm{~km}^{2}$ [130] because the arbitrary designation of this protected area would not allow for development on First Nations' land even if the First Nations supported sustainable development [90] (Table 3). Nevertheless, there is dissonance between the First Nations' perspective of development and the Government of Ontario's policy (Table 3).

To further promote economic growth in the Far North, it was proposed to delete section 12 (Far North Act, "Development if no community land use plan") [130]. This proposed change would simplify the legislation and streamline the approval process by removing restrictions on development projects [130]. By contrast, Section 14 (Far North Act, 2009, "Development if community land use plan") remained unchanged except where it was proposed to extend the timeframe from six to nine months with respect to the Lieutenant Governor in Council making an exemption order [130]. These proposed amendments of the Far North Act do not correct the fundamental flaws of the act that give ultimate power to the Government of Ontario to overrule First Nations-based land-use plans when "in the social and economic interests of Ontario" [58] (S. 14(4)).

Generating social and economic benefits for the general public of Ontario, typically non-Indigenous Ontarians, has clearly been the driving force behind the Government of Ontario's strategy for development and settlement in northern Ontario, with the Indigenous people of northern Ontario bearing the nonmonetary costs of development with little or no benefits [115]. Moreover, these policies promote a less obvious endpoint of environmental assimilation through two mechanisms, development and settlement, and the loss of control of the First Nations' homelands.

\subsection{The COVID-19 Economic Recovery Act, 2020}

The Green Energy and Green Economy Act, the Mining Amendment Act, and the Far North Act were all enacted under an Ontario Liberal Party majority government soon after the economic crisis in 2008. Interestingly, legislation that gave sweeping powers to a government minister, and did so "in the public interest", was also enacted by an Ontario majority government during the COVID-19 economic crisis of 2020, but this time by the Progressive Conservative Party. It is unusual that two fundamentally different political parties arrived at similar-sounding pieces of legislation. This observation suggests that this type of legislative language may be institutionalized, which perpetuates an injustice with respect to Indigenous people of Ontario.

In the COVID-19 Economic Recovery Act, the Lieutenant Governor in Council was given extensive powers to designate which development projects would require an Environmental Assessment (Schedule 6) or which would be exempt. The streamlining of the project approval process by removing "red tape" was in keeping with the Progressive Conservative Government's slogan of "Open for Business" [131]. Below is the section in question:

1 (1) Subsection 1 (1) of the Environmental Assessment Act is amended by adding the following definition: "designated project" means a Part II.3 [Comprehensive Environmental Assessment] project or a Part II.4 [Streamlined Environmental Assessment] project ...

Designation of projects 
3 (1) The Lieutenant Governor in Council may make regulations designating projects as projects to which Part II.3 or II.4 apply ...

\section{Declaration}

(1) Subject to subsection (1.1), the Minister may by order, with the approval of the Lieutenant Governor in Council or of such ministers of the Crown as the Lieutenant Governor in Council may designate,

(a) declare that this Act, the regulations, any provision of this Act or the regulations or any matter provided for under this Act does not apply with respect to an undertaking, class of undertakings, designated project, class of designated projects, person or class of persons;

(b) suspend or revoke the declaration;

(c) impose conditions on the declaration; or

(d) amend or revoke conditions imposed on the declaration.

\section{Same}

(1.1) The Minister shall make an order under subsection (1) only if the Minister considers that it is in the public interest to do so [added emphasis] having regard to the purpose of this Act and weighing it against the injury, damage or interference that might be caused to any person or property by the application of this Act to the undertaking, class of undertakings, designated project, class of designated projects, person or class of persons. [73] (Schedule 6)

Members of Provincial Parliament from the other political parties were critical of this removal of environmental oversight and called the Schedule 6 amendments "reckless" [132] (p. 8770) and lacking "due diligence" [133] (p. 8892) or the "precautionary approach" [134] (p. 8799). Schreiner [134] (p. 8797) of the Green Party was particularly critical:

the minister has the power to decide which projects will receive an EA [environmental assessment] and which will not. That shouldn't be decided by the minister. That should be decided by the threat of a project, the scale and scope of a project, and, most of all, by science. It should be decided by science [added emphasis].

If most of the development projects are exempted from the Government of Ontario's environmental-assessment process [135], some exempted projects (e.g., forestry) have devastating impact on waterways (e.g., mercury contamination) [136,137]. It also follows that public consultation would be eliminated for exempted projects, with the impacted communities silenced [138-140]. In addition, in exempting development projects from the environmental-assessment process, the duty to consult with Indigenous communities would not be triggered [141].

As discussed by Yurek, the Minister of the Environment, Conservation, and Parks [142] (p. 8775-8776), hydroelectric-power generation projects would be streamlined under the COVID-19 Economic Recovery Act:

We are now consulting on further practical solutions that will speed up projects,

such as ... water power generators ... to modernize [cut the red tape of] [added emphasis] Ontario's environmental assessment program.

Recently in Canada, hydroelectric-power generation was described as clean electricity [143]. The clean-energy sector was important during the COVID-19 pandemic and will be an important area of growth when Canada emerges from the COVID-19 pandemic [71]. Similarly, the Government of Ontario recently released a discussion paper on how the clean-energy sector can contribute to Ontario's economic recovery from COVID-19 while reducing greenhouse-gas emissions [144]. Fundamentally different economic crises led to similar economic-recovery pathways, with green or clean energy with the streamlining of hydroelectric projects being an important part of the plans. Unfortunately, First Nations and their homelands will bear the burden of economic recovery in Ontario for the 
sake of the non-Indigenous majority, and, with increased development, there is increased environmental assimilation.

\subsection{Moving Forward}

The way forward requires the recognition of the relations [145] that exist in these cases and our own [146]. It is not simply a matter of recognizing the collective existence of these relations; specific acknowledgement must be given to context [147] and "situational particularity" [148] (200) of each case. Through their recognition, it becomes possible to incorporate meaningful involvement from the Indigenous peoples who are at the core of these issues. Only when this is done, can it be possible to adequately address the unjust distributions of costs among Indigenous communities [148]. This process of change, reconciliation, and justice is not a simple matter, but the first steps are clear. There must be respect for multiple perspectives, so that these perspectives can be used in a complementary fashion, rather than one perspective being imposed on another [78]. As espoused by the Moose Cree First Nation [79] (pp. 4-1-4-9) of northern Ontario:

The Moose Cree have awareness, knowledge, understanding, philosophy and truth that stem from their ancient relationships with the natural world. Likewise, the Moose Cree respect that 'others' as well have different paths to awareness and knowledge of their worlds; none greater or better than the other.

The land of northern Ontario is much more than a commodity to be owned and developed. The land has been described as "our grocery store," "our garden," and "the [Albany] river, that's our highway." [149]. The land also offers a place where Indigenous knowledge can be transferred, social linkages made or strengthened, the sharing aspects of the culture practiced, and just the joy of being on the land fulfilled $[93,149]$.

It is encouraging that a new Indigenous Rights process has been initiated by the Government of Canada:

The new policy will recognize Indigenous lawmaking power; their inherent rights to land; and, in many instances, title within their traditional territories [added emphasis]. In all, the legislation and policy will support the implementation of the new United Nations Declaration on the Rights of Indigenous Peoples Act. [150] (no pagination)

There has been substantial uptake of this recent initiative, with more than 390 Indigenous communities involved in $~ 80$ Recognition of Indigenous Rights and Self-Determination discussion tables with Canada [151]. Perhaps this process could offer a viable way forward for unceded land connected to Treaty No. 9 and its adhesions [53,98]. Lastly, on 3 December 2020, Bill C-15, an act respecting the United Nations Declaration on the Rights of Indigenous Peoples [152] received First Reading in the House of Commons of Canada. If Bill C-15 obtains Royal Assent in the future, when enacted, it will implement the United Nations Declaration on the Rights of Indigenous Peoples, and may contribute to a better relationship between Canada and its First Peoples [153,154].

\section{Conclusions}

For the First Nations of northern Ontario, Treaty No. 9 and recent legislation passed by the Government of Ontario represent a threat to their homelands and their way of life. Passages in government documents allow for development in Indigenous homelands when in the interest of the government and/or "in the public interest." For example, the "taken-up" clause in Treaty No. 9, the "Exemption Orders" in the Far North Act, the "Except" stipulation in the Mining Amendment Act, and the unilateral streamlining or exemption of development projects in the Green Energy and Green Economy Act and the COVID-19 Economic Recovery Act-all these override important clauses in the documents or amend other pieces of legislation protecting the Indigenous homelands and their way of life. Each of these pieces of legislation are presented as favourable and innocuous through their title and strategies [121,155]; however, the aforementioned clauses allow for the perpetuation 
of colonial and assimilative practices at multiple points in the processes. Through an environmental-justice lens [156], the lack of meaningful involvement by Indigenous people is apparent, along with distributive-justice and recognition-justice aspects, in that the environmental costs and benefits would not be shared; the Indigenous homelands and their people would bear the brunt of the costs with little or no benefit, while their voices are drowned out.

However, from a sustainable-development viewpoint, some people would argue that hydroelectric-power generation has less of an impact on the global environment than some of the carbon-based energy alternatives, and would decrease greenhouse gases and help mitigate climate change. This argument does not take into account the scale at which impacts are being realized. From a First Nations' perspective, the local/regional impact of hydroelectric-power generation is immense. This is the disconnect between the concepts of environmental justice and sustainable development. If development is not sustainable from an Indigenous perspective, it is in reality environmental assimilation and the perpetuation of historical colonial policy. Lastly, the environmental assimilative process described for northern Ontario can globally be seen in other countries, where there are treaties with Indigenous nations (e.g., USA) and especially where there are no treaties (e.g., Australia).

Funding: This research was funded by the Social Sciences and Humanities Research Council of Canada, grant number 435-2016-135.

Institutional Review Board Statement: Not applicable.

Informed Consent Statement: Not applicable.

Data Availability Statement: Not applicable.

Acknowledgments: I thank the reviewers for their comments.

Conflicts of Interest: The authors declare no conflict of interest. The funders had no role in the design of the study; in the collection, analyses, or interpretation of data; in the writing of the manuscript, or in the decision to publish the results.

\section{References}

1. Commission for Racial Justice. Toxic Wastes and Race in the United States; United Church of Christ: Cleveland, OH, USA, 1987.

2. Bullard, R.D.; Mohai, P.; Saha, R.; Wright, B. Toxic Wastes and Race at Twenty 1987-2007; United Church of Christ: Cleveland, OH, USA, 2007.

3. USEPA. Environmental Justice. United States Environmental Protection Agency, 2021. Available online: https://www.epa.gov / environmentaljustice (accessed on 1 April 2021).

4. Scott, D.N. What is environmental justice? Osgoode Legal Stud. Res. Pap. 2014, 10, 72. [CrossRef]

5. Lindgren, R.D. Access to Environmental Justice in Canada: The Road Ahead. Canadian Environmental Law Association. 2019. Available online: https:/ / cela.ca/access-to-environmental-justice-in-canada-the-road-ahead/ (accessed on 2 March 2021).

6. McGregor, D.; Whitaker, S.; Sritharan, M. Indigenous environmental justice and sustainability. Curr. Opin. Environ. Sustain. 2020, 43, 35-40. [CrossRef]

7. Agyeman, J.; Bullard, R.D.; Evans, B. Exploring the nexus: Bringing together sustainability, environmental justice and equity. Space Polity 2002, 6, 77-90. [CrossRef]

8. United Nations General Assembly. United Nations Conference on the Human Environment. 15 December 1972.

9. Gibson, R.; Hassan, S. Sustainability Assessment: Criteria and Processes; Earthscan: London, UK, 2005.

10. United Nations General Assembly. United Nations Conference on Environment and Development; United Nations General Assembly: New York, NY, USA, 22 December 1989.

11. World Conference on Environment and Development 1987. Available online: https://sustainabledevelopment.un.org/content/ documents/5987our-common-future.pdf (accessed on 23 July 2021).

12. World Public Meeting on Culture. September 2002. Available online: https://undocs.org/pdf?symbol=en/A/Conf.199/20 (accessed on 23 July 2021).

13. Agenda 21: Earth Summit: The United Nations Programme of Action from Rio, 1993 UNEP. Available online: https:// sustainabledevelopment.un.org/content/documents / Agenda21.pdf (accessed on 23 July 2021).

14. United Cities and Local Governments. (2002-2004). Agenda 21 for Culture. Available online: https://www.agenda21culture.net/ 2002-2004 (accessed on 23 July 2021).

15. Nishiiyuu Council of Elders. What You Do to Eeyou Istchee (Our Land), You Do to Eeyouch (Our People). Available online: https://archives.bape.gouv.qc.ca/sections/mandats/uranium-enjeux/documents/MEM26.pdf (accessed on 17 April 2021). 
16. Constitution Act. A Consolidation of The Constitution Acts 1867 to 1982, Department of Justice Canada, Consolidated as of 1 January 2013; Public Works and Government Services Canada: Ottawa, ON, Canada, 1982.

17. Cannon, M. Revisiting histories of legal assimilation, racialized injustice, and the future of Indian status in Canada. Aborig. Pol. Res. Consort. Int. 2007, 97, 35-48.

18. Leslie, J.F. The Indian Act: An historical perspective. Can. Parl. Rev. 2002, 25, 23-27.

19. Truth and Reconciliation Commission of Canada. Honouring the Truth, Reconciling for the Future; McGill-Queen's University Press: Montreal, QC, Canada, 2015.

20. Gradual Civilization Act. An Act to Encourage the Gradual Civilization of the Indian Tribes in This Province, and to Amend the Laws Respecting Indians; CAP. XXVI: Province of Canada, ON, Canada, 1857.

21. Brownlie, R.J. 'A better citizen than lots of white men': First Nations enfranchisement-An Ontario case study. Can. Hist. Rev. 2006, 87, 29-52. [CrossRef]

22. Kirby, C. Reconstituting Canada: The enfranchisement and disenfranchisement of 'Indians' circa 1837-1900. Univ. Tor. Law J. 2019, 69, 497-539. [CrossRef]

23. Gradual Enfranchisement Act. An Act for the Gradual Enfranchisement of Indians, the Better Management of Indian Affairs, and to Extend the Provisions of the Act 31st Victoria; Chapter 42; Dominion of Canada: ON, Canada, 1869.

24. Lawrence, B. Gender, race, and the regulation of Native identity in Canada and the United Sates: An overview. Hypatia 2003, 18, 3-31. [CrossRef]

25. Schmidt, R.W. American Indian identity and blood quantum in the 21st century: A critical review. J. Anthr. 2011, 549521. [CrossRef]

26. Spruhan, P. CDIB: The role of the certificate of degree of Indian blood in defining Native American legal identity. Am. Indian Law J. 2018, 6, 169-196. [CrossRef]

27. Indian Act, 1876. Consolidation Indian Act R.S.C., 1985, c 1-5, Current to 17 June 2020; Minister of Justice; Government of Canada: Ottawa, ON, Canada, 1985.

28. Assembly of First Nations. Enfranchisement. Legal Affairs and Justice; Assembly of First Nations; undated.

29. Dominion of Canada. Official Report of the Debates of the House of Commons of the Dominion of Canada. Fourth Session-Thirteenth Parliament. 10-11 George V, 1920; Printer to the King's Most Excellent Majesty: Ottawa, ON, Canada, 1920; Volume CXLV.

30. Government of Canada. Statement of the Government of Canada on Indian Policy [the "White Paper"]; Government of Canada: Ottawa, ON, Canada, 1969.

31. Indian Chiefs of Alberta. Citizen Plus [the "Red Paper"] 1970. Repr. Aborig. Policy Stud. 2011, 1, $188-211$.

32. Hawthorn, H.B. A Survey of the Contemporary Indians of Canada. Part 1; Indian Affairs Branch: Ottawa, ON, Canada, 1966.

33. Hawthorn, H.B. A Survey of the Contemporary Indians of Canada. Part 2; Indian Affairs Branch: Ottawa, ON, Canada, 1967.

34. Bill C-31. Indian Act R.S.C. 1985 Amendment. Available online: https://laws-lois.justice.gc.ca/eng/acts/i-5/ (accessed on 23 July 2021).

35. Clatworthy, S. Re-Assessing the Population Impacts of Bill C-31; Four Directions Project Consultants: Winnipeg, MB, Canada, 2004.

36. Clatworthy, S. Indian Registration, Membership and Population Change in First Nations Communities; Four Directions Project Consultants: Winnipeg, MB, Canada, 2005.

37. Bill S-3. An Act to Amend the Indian Act in Response to the Superior Court of Quebec Decision in Descheneaux c. Canada (Procureur General). S.C. c. 25, 2017. Available online: https://laws-lois.justice.gc.ca/eng/annualstatutes/2017_25/page-1.html (accessed on 23 July 2021).

38. Clatworthy, S. An Assessment of the Population Impacts of Select Hypothetical Amendments to Section 6 of the Indian Act; Four Directions Project Consultants: Winnipeg, MB, Canada, 2017.

39. Truth and Reconciliation Commission of Canada. Canada's Residential Schools: The History, Part 1, Origins to 1939; McGill-Queen's University Press: Montreal, QC, Canada, 2015; Volume 1.

40. Truth and Reconciliation Commission of Canada. Honouring the Truth, Reconciling for the Future. Summary of the Final Report of the Truth and Reconciliation Commission of Canada; McGill-Queen's University Press: Montreal, QC, Canada, 2015.

41. Bombay, A.; McQuaid, R.J.; Young, J.; Sinha, V.; Currie, V.; Anisman, H.; Matheson, K. Familial attendance at Indian residential school and subsequent involvement in the child welfare system among Indigenous adults born during the Sixties Scoop era. First Peoples Child Fam. Rev. 2020, 15, 62-79. [CrossRef]

42. Cardinal, S.W. A framework for Indigenous adoptee reconnection: Reclaiming language and identity. Can. J. New Sch. Ed. 2016, 7, 84-93.

43. Sinclair, R. The Indigenous child removal system in Canada: An examination of legal decision-making and racial bias. First Peoples Child Fam. Rev. 2016, 11, 8-18.

44. Briggs, L.; Dubinsky, K. The politics of history and the history of politics. Am. Indian Q. 2013, 37, 129-135. [CrossRef]

45. Truth and Reconciliation Commission of Canada. Introduction; McGill-Queen's University Press: Montreal, QC, Canada, 2015.

46. Government of Ontario. Map of Ontario Treaties and Reserves. Available online: https://www.ontario.ca/page/map-ontariotreaties-and-reserves\#treaties (accessed on 18 April 2021).

47. The Canada (Ontario) Boundary Act. 1889. Available online: https://digitalcommons.osgoode.yorku.ca/cgi/viewcontent.cgi? referer=https: / / www.google.com / \&httpsredir=1\&article=4215\&context=rso (accessed on 18 April 2021). 
48. Ontario Boundaries Extension Act (Can. 1912). Available online: https:/ / digitalcommons.osgoode.yorku.ca/cgi/viewcontent. cgi?referer=https: / / www.google.com/\&httpsredir=1\&article=2152\&context=rso (accessed on 18 April 2021).

49. Aboriginal Affairs and Northern Development Canada. Pre-1975 Treaties. Available online: https://www.aadnc-aandc. gc.ca/DAM/DAM-INTER-HQ-AI/STAGING/texte-text/mprm_treaties_th-ht_canada_1371839430039_eng.pdf (accessed on 18 April 2021).

50. Royal Proclamation of 1763. 1763. Available online: https://exhibits.library.utoronto.ca/items/show/2470 (accessed on 18 April 2021).

51. Macrae, J. J Macrea, Office of the Inspector of Indian Agencies and Reserves, Memorandum Dated 3 June 1901, for the Superintendent General of Indian Affairs. Treaty No. 9 The James Bay Treaty-Reports, Correspondence, Drafts, Memorandums, Order in Council (MIKAN No. 2082958 or R216-244-6-E; Volume 3033; File 235,225 Part 1). Available online: https: / / www.bac-lac.gc. ca/eng/CollectionSearch/Pages / record.aspx?app=fonandcol\&IdNumber=2082958\&new=-8585745425513676204 (accessed on 23 July 2021).

52. The James Bay Treaty-Treaty No. 9. 1964. The James Bay Treaty-Treaty No. 9 (Made in 1905 and 1906) and Adhesions Made in 1929 and 1930; Reprinted from the edition of 1931 by Roger Duhamel, Cat No. Ci 72-0964; Queens Printer and Controller of Stationary: Ottawa, ON, Canada, 1964.

53. Tsuji, L.J.S.; Tsuji, S.R.J. Development on Indigenous Homelands and the Need to Get Back to Basics with Scoping: Is there Still "Unceded" Land in Northern Ontario, Canada, with respect to Treaty No. 9 and its Adhesions? Int. Indig. Policy J. 2021, 12, 1-49. [CrossRef]

54. Vincent, T.; Archdeacon, T. Vincent, Stonewall, Manitoba, Letter Dated 14 July 1902, to Superintendent General Indian Affairs. Treaty No. 9 The James Bay Treaty-Reports, Correspondence, Drafts, Memorandums, Order in Council (MIKAN No. 2082958 or R216-244-6-E; Volume 3033; File 235,225 Part 1). Available online: https: / www.bac-lac.gc.ca/eng/CollectionSearch/Pages / record.aspx?app=fonandcol\&IdNumber=2082958\&new=-8585745425513676204 (accessed on 23 July 2021).

55. Pedley, F.F. Pedley, Deputy Superintendent General Indian Affairs, Memorandum (Final Version) Dated 17 August 1903 , to C. Sifton, Minister of Interior, and Superintendent General Indian Affairs. Treaty No. 9 The James Bay Treaty-Reports, Correspondence, Drafts, Memorandums, Order in Council (MIKAN No. 2082958 or R216-244-6-E; Volume 3033; File 235,225 Part 1). Available online: https: / / www.bac-lac.gc.ca/eng/CollectionSearch/Pages / record.aspx?app=fonandcol\&IdNumber=20 82958\&new =-8585745426240422147 (accessed on 23 July 2021).

56. Barrell, R.; Davis, E. The evolution of the financial crisis of 2007-8. Natl. Inst. Econ. Rev. 2008, 206, 5-14. [CrossRef]

57. Green Energy and Green Economy Act, 2009, S.O. 2009, c. 12. (ON, Canada). Available online: https://www.ontario.ca/laws/ statute/s09012 (accessed on 23 July 2021).

58. Mining Amendment Act, 2009. S.O. 2009, c. 21. Available online: https://www.ontario.ca/laws/statute/s09021 (accessed on 23 July 2021).

59. Far North Act, 2010. S.O. 2010, c. 18. Available online: https://www.ontario.ca/laws/statute/10f18? search=Far+North+act (accessed on 23 July 2021).

60. McGuinty, D. Ontario, Official Report of Debates of the Legislative Assembly (Hansard), 39th Parl, 1st Sess, No. 114 (25 February 2009) at 5027-5028. Available online: https://www.ola.org/sites/default/files/node-files/hansard/document/pdf/2009/200902/house-document-hansard-transcript-1-EN-25-FEB-2009_L114.pdf (accessed on 23 July 2021).

61. Smitherman, G. Ontario, Official Report of Debates of the Legislative Assembly (Hansard), 39th Parl, 1st Sess, No. 112 (23 February 2009) at 4951-4952. Available online: https:/ /www.ola.org/sites/default/files/node-files/hansard/document/pdf/20 09/2009-02/house-document-hansard-transcript-1-EN-23-FEB-2009_L112.pdf (accessed on 23 July 2021).

62. Legislative Assembly of Ontario. Acts Affected-Bill 150. Available online: https://www.ola.org/en/legislative-business/bills/ parliament-39/session-1/bill-150/acts-affected (accessed on 14 April 2021).

63. Bedard, M. Background Paper. Omnibus Bills: Frequently Asked Questions. Publication No. 2012-79E; Library of Parliament: Ottawa, ON, Canada, 2012.

64. Parliament of Canada. House of Commons Canada. Glossary of Parliamentary Procedure. 2021. Available online: https: / /www.ourcommons.ca/About/Glossary/Index-e.html\#LetterO (accessed on 14 April 2021).

65. Kirchhoff, D.; Tsuji, L. Reading between the lines of the "Responsible Resource Development" rhetoric: The use of omnibus bills to "streamline" Canadian environmental legislation. Impact Assess. Proj. Apprais. 2014, 32, 108-120. [CrossRef]

66. McRobert, D.; Tennent-Riddell, J.; Walker, C. Ontario's Green Economy and Green Energy Act Why a Well-Intentioned Law is Mired in Controversy and Opposed by Rural Communities. Renew. Energy Law Pol. Rev. 2016, 7, 91-112.

67. Drake, K. The Trials and Tribulations of Ontario's Mining Act: The Duty to Consult and Anishinaabek Law. McGill J. Sustain. Dev. Law 2015, 11, 184-218.

68. Gardner, H.L.; Tsuji, S.R.J.; McCarthy, D.D.; Whitelaw, G.S.; Tsuji, L.J.S. The Far North Act (2010) Consultative Process: A New Beginning or the Reinforcement of an Unacceptable Relationship in Northern Ontario, Canada? Int. Indig. Pol. J. $2012,3,7$. [CrossRef]

69. Manjili, R.; Zarei, M.; Habibi, M.; Manjili, M. COVID-19 as an acute inflammatory disease. J. Immunol. 2020, 205, 12-19. [CrossRef]

70. World Health Organization. Origin of SARS-CoV-2, 26 March 2020. World Health Organization, License: CC BY-NC-SA 3.0 IGO. 2020. Available online: https://apps.who.int/iris/handle/10665/332197 (accessed on 14 April 2021). 
71. Statistics Canada. The Social and Economic Impacts of COVID-19: A Six-Month Update. Catalogue no. 11-631-x; Government of Canada: Ottawa, ON, Canada, 2020.

72. Government of Ontario. A Framework for Reopening our Province. Stage 3; Government of Ontario: Toronto, ON, Canada, 2020.

73. COVID-19 Economic Recovery Act, 2020. S.O. 2020, c.18. Available online: https://www.ontario.ca/laws/statute/s20018 (accessed on 23 July 2021).

74. Government of Ontario. About Ontario. Available online: http://www.ontario.ca/page/about-ontario (accessed on 18 April 2021).

75. Spotton, N. A Profile of Aboriginal Peoples in Ontario; Ipperwash Inquiry: Toronto, ON, Canada, 2006.

76. Chiefs of Ontario. Chiefs of Ontario: About Us. Available online: http:/ / www.chiefs-of-ontario.org/about-us/ (accessed on 22 January 2020).

77. Beardy, S. G32 Standing Committee on the General Government, Hearings, Bill 173 (Mining Amendment Act, 2009, Far North Act, 2009). 2009. Available online: https://www.ola.org/en/legislative-business/bills/parliament-39/session-1/bill-173/debates (accessed on 1 January 2020).

78. Tsuji, L.J.S.; Ho, E. Traditional environmental knowledge and western science: In search of common ground. Can. J. Nat. Stud. 2002, 22, 327-360. Available online: http:/ / www3.brandonu.ca/cjns/22.2/cjnsv.22no.2_pg327-360.pdf (accessed on 23 July 2021).

79. Moose Cree First Nation. Ontario Power Generation and Moose Cree First Nation Comprehensive Study Report: Lower Mattagami River Hydroelectric Complex Project. 2009. Available online: https:/ / ceaa-acee.gc.ca/050/documents_staticpost/26 302/38969E.pdf (accessed on 18 April 2021).

80. McKay, S. G-34. Legislative Assembly of Ontario, First Session, 39th Parliament Official Report of Debates (Hansard) Tuesday 11 August 2009. Standing Committee on the General Government, Mining Amendment Act, 2009, Far North Act, 2009. Available online: https:/ / www.ola.org/sites/default/files/node-files/hansard/document/pdf/2009/2009-08/committee-transcript-1EN-11-AUG-2009_G034.pdf (accessed on 18 April 2021).

81. Solomon, J. G35 Standing Committee on the General Government, Hearings, Bill 173 (Mining Amendment Act, 2009 ). 2009. Available online: https://www.ola.org/en/legislative-business/bills/parliament-39/session-1/bill-173/debates (accessed on 18 April 2021).

82. Solomon, A. G35 Standing Committee on the General Government, Hearings, Bill 173 (Mining Amendment Act, 2009 ). 2009. Available online: https:/ / www.ola.org/en/legislative-business/bills/parliament-39/session-1/bill-173/debates (accessed on 18 April 2021).

83. Beardy, F. G35 Standing Committee on the General Government, Hearings, Bill 173 (Mining Amendment Act, 2009). Available online: https:/ / www.ola.org/en/legislative-business/bills/parliament-39/session-1/bill-173/debates (accessed on 18 April 2021).

84. Hunter, G. G35 Standing Committee on the General Government, Hearings, Bill 173 (Mining Amendment Act, 2009 ). 2009. Available online: https://www.ola.org/en/legislative-business/bills/parliament-39/session-1/bill-173/debates (accessed on 18 April 2021).

85. Babin, D. G35 Standing Committee on the General Government, Hearings, Bill 173 (Mining Amendment Act, 2009). 2009. Available online: https:/ / www.ola.org/en/legislative-business/bills/parliament-39/session-1/bill-173/debates (accessed on 18 April 2021).

86. Tsuji, L.J.S.; Nieboer, E. A question of sustainability in Cree harvesting practices: The seasons, technological and cultural changes in the western James Bay region of northern Ontario, Canada. Can. J. Nat. Stud. 1999, 19, 169-192. Available online: http:/ / www3.brandonu.ca/cjns/19.1/cjnsv19no1_pg169-192.pdf (accessed on 23 July 2021).

87. Tsuji, L.J.S.; McCarthy, D.D.; Whitelaw, G.S.; McEachren, J. Getting back to basics: The Victor Diamond Mine environmental assessment scoping process and the issue of family-based traditional lands versus registered traplines. Impact Assess. Proj. Apprais. 2011, 29, 37-47. [CrossRef]

88. Whitelaw, G.S.; McEachren, J.; McCarthy, D.D.; Tsuji, L.J.S. The Use of Traditional Environmental Knowledge to Resolve the Issue of Family-based Traditional Lands versus Registered Traplines: The Victor Diamond Mine Comprehensive Environmental Assessment Scoping Process. Can. J. Nat. Stud. 2012, 32, 141-158.

89. Corston, K. G35 12 August 2009 Standing Committee on the General Government, Hearings, Bill 173 (Mining Amendment Act, 2009). 2009. Available online: https://www.ola.org/en/legislative-business/bills/parliament-39/session-1/bill-173/debates (accessed on 23 July 2021).

90. Hall, T. G36 13 August 2009, Standing Committee on the General Government, Hearings, Bill 173 (Mining Amendment Act, 2009 ). Available online: https://www.ola.org/en/legislative-business/bills/parliament-39/session-1/bill-173/debates (accessed on 1 January 2020).

91. Kapashesit, R. Ontario, Standing Committee on General Government (Hansard), 39th Parl, 1st Sess, G35 (12 August 2009 ) at 957. Available online: https://www.ola.org/sites/default/files/node-files/hansard/document/pdf/2009/2009-08/committeetranscript-1-EN-12-AUG-2009_G035.pdf (accessed on 23 July 2021).

92. Armstrong, J. The Elusive Statement of Treaty Principles James Bay Treaty No. 9. NAN-Canada Treaty Discussion Forum; Armstrong Historical Research Services: Ottawa, ON, Canada, 2008.

93. Tsuji, L.J.S.; Tsuji, S.R.J.; Zuk, A.M.; Davey, R.; Liberda, E.N. Harvest Programs in First Nations of Subarctic Canada: The Benefits Go Beyond Addressing Food Security and Environmental Sustainability Issues. Int. J. Environ. Res. Public Health 2020, 17, 8113. [CrossRef] 
94. Louttit, S. Oral Promises in the Lost Treaty 9 Diaries. PowerPoint Presentation at the Mushkegowuk Senior Management and First Nations Senior Management Meeting. Treaty \#9 and Oral Promises of the Treaty; Mushkegowuk Council: Mushkegowuk Territory, ON, Canada, 2010.

95. Mushkegowuk Council. Sharing the Land: A Mushkegowuk Treaty Awareness Initiative. 2021. Available online: http: //www.mushkegowuk.com/?page_id=4008 (accessed on 18 April 2021).

96. Macklem, P. The Impact of Treaty 9 on natural resource development in Northern Ontario. In Aboriginal and Treaty Rights in Canada: Essays on Law, Equity, and Respect for Difference (pp. 97-132); Asch, M., Ed.; UBC Press: Vancouver, BC, Canada, 1997.

97. Long, J.S. Treaty No. 9. Making the Agreement to Share the Land in Far Northern Ontario in 1905; McGill-Queen's University Press: Montreal, QC, Canada, 2010.

98. Tsuji, S.R.J.; Tsuji, L.J.S. Treaty No. 9 and the Question of "Unceded" Land South of the Albany River in Subarctic Ontario. Canada. Arctic. in press.

99. Adhesions to Treaty Number Nine, 1929. The James Bay Treaty-Treaty No. 9. (Made in 1905 and 1906) and Adhesions Made in 1929 and 1930; Reprinted from the edition of 1931 by Roger Duhamel, Cat. No. Ci 72-0964; Queen's Printer and Controller of Stationary: Ottawa, ON, Canada, 1964.

100. Tsuji, L.J.S.; Daradich, D.; Gomez, N.; Hay, C.; Mitrovica, J.X. Sea Level Change in the Western James Bay Region of Subarctic Ontario: Emergent Land and Implications for Treaty No. 9. Arctic 2016, 69, 99-107. [CrossRef]

101. Pritchard, C.; Sistili, B.; General, Z.; Whitelaw, G.S.; McCarthy, D.D.; Tsuji, L.J.S. Akimiski Island, Nunavut Canada: A Test of Inuit Title. Can. J. Nativ. Stud. 2010, 30, 407-414. Available online: http://www3.brandonu.ca/cjns/30.2/09tsuji.pdf (accessed on 23 July 2021).

102. General, Z.; Tsuji, S.R.J.; Tsuji, L.J.S. Akimiski Island, Nunavut, Canada: An Island in dispute. Can. J. Nativ. Stud. 2017, $37,1-25$.

103. Tsuji, L.J.S.; Gomez, N.; Mitrovica, J.X.; Kendall, R. Post-glacial isostatic adjustment and global warming in subarctic Canada: Implications for islands of the James Bay region. Arctic 2009, 62, 458-467. [CrossRef]

104. Tsuji, L.J.S.; General, Z.; Tsuji, S.R.J.; Powell, E.; Latychev, K.; Clark, J.; Mitrovica, J.X. Akimiski Island, Nunavut, Canada: The Use of Cree Oral History and Sea-level Retrodiction to Resolve Aboriginal Title. Arctic 2020, 73, 421-432. [CrossRef]

105. Scott, D.C.; Stewart, S.; MacMartin, D.G. James Bay Treaty No. 9-Treaty No. 9-November 6, 1905; Treaty No. 9-James Bay Treaty-Annuity interest payments and accounts (MIKAN No. 2083329 or R216-244-6-E; Volume 3034 File Part 4; File 235,225); Government Printing Bureau: Ottawa, ON, Canada, 1907.

106. Drake, K. The Impact of St Catherine's Milling. Law Society of Upper Canada. Special Lectures 2017. Canada at 150: The Charter and the Constitution; Law Society of Upper Canada: Toronto, ON, Canada, 2018.

107. Armstrong, J. The Role of Ontario in the Making and Implementation of Treaty Nine: The Taking up Clause and Harvesting Rights; Armstrong Historical Research Services: Ottawa, ON, Canada, 2013.

108. MacMartin, D.G. Treaty No. 9 Diary. 1905. Available online: https://www.mushkegowuk.com/?page_id=3768 (accessed on 18 April 2021).

109. Stewart, S. The James Bay Treaty: Treaty 9 Diary. 1905. Available online: https://www.mushkegowuk.com/?page_id=3768 (accessed on 18 April 2021).

110. Archives of Manitoba. Hudson's Bay Company Archives-HBC fur Trade Post Map. Available online: https://www.gov.mb.ca/ chc/archives/hbca/post_maps/quebec.html\#north-qc (accessed on 31 March 2021).

111. Scott, D.C.; Stewart, S.; MacMartin, D.G. The James Bay Treaty-Treaty No. 9. (Made in 1905 and 1906) and Adhesions Made in 1929 and 1930. 1905 and 1906 Reports; Reprinted from the edition of 1931 by Roger Duhamel, Cat. No. Ci 72-0964; Queen's Printer and Controller of Stationary: Ottawa, ON, Canada, 1964.

112. Feit, H.A. Hunting and the quest for power: The James Bay Cree and whitemen in the 20th century. In Native Peoples: The Canadian Experience, 2nd ed.; Morrison, R.B., Wilson, C.R., Eds.; McCelland and Stewart: Toronto, ON, Canada, 1995.

113. James Bay and Northern Quebec Agreement. 1975. Available online: http://www.naskapi.ca/documents/documents/JBNQA. pdf (accessed on 17 April 2021).

114. Macfarlane, D.; Kitay, P. Hydraulic imperialism: Hydroelectric development and Treaty 9 in the Abitibi region. Am. Rev. Can. Stud. 2016, 46, 380-397. [CrossRef]

115. Macfarlane, D.; Watson, A.; Knight, W. Hydro democracy: Water power and political power in Ontario. Sci. Can. 2018, 40, 1-18. [CrossRef]

116. Cryderman, D.; Letourneau, L.; Miller, F.; Basu, N. An ecological and human biomonitoring investigation of mercury contamination at the Aamjiwnaang First Nation. Ecohealth 2016, 13, 784-795. [CrossRef]

117. O'Donnell, V.; LaPointe, R. Response Mobility and the Growth of the Aboriginal Identity Population, 2006-2011 and 2011-2016; Statistics Canada: Ottawa, ON, Canada, 2019.

118. Statistics Canada. Focus on Geography Series, 2016 Census. Statistics Canada Catalogue No. 98-404-X2016001; Data Products, 2016 Census; Government of Canada: Ottawa, ON, Canada, 2017. Available online: https://www12.statcan.gc.ca/census-recensement/20 16/as-sa/fogs-spg/Facts-PR-Eng.cfm?TOPIC=9\&LANG=Eng\&GK=PR\&GC=35 (accessed on 27 December 2019).

119. Statistics Canada. Canada's Population Estimates, Third Quarter 2019; Statistics Canada: Ottawa, ON, Canada, 2019.

120. Statistics Canada. Projections of the Aboriginal Populations, Canada, Provinces and Territories 2001 to 2017; Minister of Industry: Ottawa, ON, Canada, 2005.

121. Tsuji, S.R.J. Fiduciary Responsibility and the Green Energy Act, 2009 (Ontario, Canada). Environ. Justice 2020, 14, 76-85. [CrossRef] 
122. Moridi, R. Ontario, Official Report of Debates of the Legislative Assembly (Hansard), 39th Parl, 1st Sess, No. 120 (9 March 2009) at 5338. Available online: https://www.ola.org/sites/default/files/node-files/hansard/document/pdf/2009/2009-03/housedocument-hansard-transcript-1-EN-09-MAR-2009_L120.pdf (accessed on 23 July 2021).

123. Green Energy Repeal Act, 2018. S.O. 2018, c. 16. Available online: https://www.ontario.ca/laws/statute/s18016 (accessed on 23 July 2021).

124. Government of Ontario. Green Energy and Green Economy Act, 2009, S.O. 2009, c. 12, Sched. A. Available online: https: //www.ontario.ca/laws/statute/09g12 (accessed on 18 April 2021).

125. Schreiner, M. Ontario, Official Report of Debates of the Legislative Assembly (Hansard), 42nd Parl, 1st Sess, No. 178 (21 July 2020). Available online: https://www.ola.org/sites/default/files/node-files/hansard/document/pdf/2020/2020-07/21-JUL2020_L178.pdf (accessed on 23 July 2021).

126. Bhomik, C.; Bhowmik, S.; Ray, A.; Pandey, K.M. Optimal green energy planning for sustainable development: A review. Renew. Sustain. Energy Rev. 2017, 71, 796-813. [CrossRef]

127. Moore, A. Ontario, Standing Committee on General Government (Hansard), 39th Parl, 1st Sess, G35 (12 August 2009$)$ at 963. Available online: https://www.ola.org/sites/default/files/node-files/hansard/document/pdf/2009/2009-08/committeetranscript-1-EN-12-AUG-2009_G035.pdf (accessed on 23 July 2021).

128. Slipperjack, A. Ontario, Standing Committee on General Government (Hansard), 39th Parl, 1st Sess, G35 (12 August 2009 ) at 948 949. Available online: https:/ /www.ola.org/sites/default/files/node-files/hansard/document/pdf/2009/2009-08/committeetranscript-1-EN-12-AUG-2009_G035.pdf (accessed on 23 July 2021).

129. Ontario's Regulatory Registry. Proposed Far North Act Amendments. Available online: https://ero.ontario.ca/notice/019-2684 (accessed on 16 March 2021).

130. Environmental Registry Ontario. Proposed Environmental Assessment Act (EAA) Amendments in the COVID 19-Economic Recovery Act. Available online: https:/ / ero.ontario.ca/notice/019-2051 (accessed on 16 March 2021).

131. Government of Ontario. Open for Business. Available online: https://www.ontario.ca/page/open-business (accessed on 23 December 2020).

132. Vanthof, J. Ontario, Official Report of Debates of the Legislative Assembly (Hansard), 42nd Parl, 1st Sess, No. 176a (15 July 2020 ) at 8770. Available online: https:/ / www.ola.org/sites/default/files/node-files/hansard/document/pdf/2020/2020-07/15-JUL2020_L176B.pdf (accessed on 23 July 2021).

133. Arthur, I. Ontario, Official Report of Debates of the Legislative Assembly (Hansard), 42nd Parl, 1st Sess, No. 178 (21 July 2020 ) at 8928-8929. Available online: https://www.ola.org/sites/default/files/node-files/hansard/document/pdf/2020/2020-07/21JUL-2020_L178.pdf (accessed on 23 July 2021).

134. Schreiner, M. Ontario, Official Report of Debates of the Legislative Assembly (Hansard), 42nd Parl, 1st Sess, No. 176b (15 July 2020) at 8799. Available online: https:/ /www.ola.org/sites/default/files/node-files/hansard/document/pdf/2020/2020-07/15JUL-2020_L176B.pdf (accessed on 23 July 2021).

135. Bell, J. Ontario, Official Report of Debates of the Legislative Assembly (Hansard), 42nd Parl, 1st Sess, No. 176b (15 July 2020 ). Available online: https:/ / www.ola.org/sites/default/files/node-files/hansard/document/pdf/2020/2020-07/15-JUL-2020 _L176B.pdf (accessed on 23 July 2021).

136. Porvari, P.; Verta, M.; Munthe, J.; Haapanen, M. Forestry Practices Increase Mercury and Methyl Mercury Output from Boreal Forest Catchments. Environ. Sci. Tech. 2003, 37, 2389-2393. [CrossRef]

137. Kronberg, R.; Drott, A.; Jiska, M.; Wiederhold, J.G.; Bjorn, E.; Skyllberg, U. Forest harvest contribution to Boreal Freshwater Methyl Mercury Load. Glob. Biogeochem. Cycles 2016, 30, 825-843. [CrossRef]

138. Begum, D. Ontario, Official Report of Debates of the Legislative Assembly (Hansard), 42nd Parl, 1st Sess, No. 178 (21 July 2020). Available online: https:/ / www.ola.org/sites/default/files/node-files/hansard/document/pdf/2020/2020-07/21-JUL-2020 _L178.pdf (accessed on 23 July 2021).

139. Hunter, M. Ontario, Official Report of Debates of the Legislative Assembly (Hansard), 42nd Parl, 1st Sess, No. 178 (21 July 2020 ) at 8929. Available online: https:/ / www.ola.org/sites/default/files/node-files/hansard/document/pdf/2020/2020-07/21-JUL2020_L178.pdf (accessed on 23 July 2021).

140. Karpoche, B. Ontario, Official Report of Debates of the Legislative Assembly (Hansard), 42nd Parl, 1 st Sess, No. 178 (21 July 2020). Available online: https:/ / www.ola.org/sites/default/files/node-files/hansard/document/pdf/2020/2020-07/21-JUL2020_L178.pdf (accessed on 23 July 2021).

141. Tsuji, S.R.J. Economic Recovery in Response to Worldwide Crises: Fiduciary Responsibility and the Legislative Consultative Process with Respect to Bill 150 (Green Energy and Green Economy Act, 2009) and Bill 197 (COVID-19 Economic Recovery Act, 2020) in Ontario, Canada. Revised Manuscript in Review.

142. Yurek, J. Ontario, Official Report of Debates of the Legislative Assembly (Hansard), 42nd Parl, 1st Sess, No. 176b (15 July 2020) at 8779 and 8821. Available online: https://www.ola.org/sites/default/files/node-files/hansard/document/pdf/2020/2020-07/1 5-JUL-2020_L176B.pdf (accessed on 23 July 2021).

143. Government of Canada. Powering Our Future with Clean Electricity. 2020. Available online: https://www.canada. $\mathrm{ca} /$ en/services/environment/weather/climatechange/climate-action/powering-future-clean-energy.html (accessed on 23 December 2020). 
144. Government of Ontario. Ontario Low-Carbon Hydrogen Strategy Discussion Paper; Government of Ontario: Toronto, ON, Canada, 2016.

145. Scholsberg, D. Reconceiving Environmental Justice: Global Movements and Political Theories. Environ. Politics 2004, 13, 517-540. [CrossRef]

146. Walker, G. Environmental Justice: Concepts, Evidence and Politics; Routledge: New York, NY, USA, 2012.

147. Parsons, M.; Taylor, L.; Crease, R. Indigenous Environmental Justice within Marine Ecosystems: A Systematic Review of the Literature on Indigenous Peoples' Involvement in Marine Governance and Management. Sustainability 2021, 13, 4217. [CrossRef]

148. Whyte, K.P. The Recognition Dimensions of Environmental Justice in Indian Country. Environ. Justice 2011, 4, 199-205. [CrossRef]

149. Minkin, D.; Whitelaw, G.S.; McCarthy, D.D.; Tsuji, L.J.S. Cultural Preservation and Empowerment through Land Use Planning: Identification of Values in Support of Fort Albany First Nation, Ontario, Canada, Community Based Land Use Planning. Can. J. Nativ. Stud. 2014, 34, 1-22.

150. Crown-Indigenous Relations and Northern Affairs Canada. Overview of a Recognition and Implementation of Indigenous Rights Framework. 2018. Available online: https://www.rcaanc-cirnac.gc.ca/eng/1536350959665/1539959903708 (accessed on 18 April 2021).

151. Crown-Indigenous Relations and Northern Affairs Canada. About Recognition of Indigenous Rights and Self-Determination Discussion Tables. 2019. Available online: https:/ / www.rcaanc-cirnac.gc.ca/eng/1511969222951/1529103469169\#chp7 (accessed on 18 April 2021).

152. Bill C-15, An Act Respecting the United Nations Declaration on the Rights of Indigenous Peoples; Parliament of Canada, 2020. Available online: https: / / www.parl.ca/LegisInfo/BillDetails.aspx?Language=en\&Mode=1\&billId=11007812 (accessed on 23 July 2021 ).

153. Department of Justice Canada. Implementing the United Nations Declaration on the Rights of Indigenous Peoples the Declaration; Department of Justice Canada: Ottawa, ON, Canada, 2020.

154. Department of Justice Canada. Bill C-15: United Nations Declaration on the Rights of Indigenous Peoples Act; Department of Justice Canada: Ottawa, ON, Canada, 2020.

155. Tsuji, S.R.J. Beware of Green Labelling: The Green Energy Act (2009) and the "Consultative" Process or Lack Thereof in Ontario, Canada. Int. Indig. Policy J. 2021, in press.

156. Agyeman, J. Environmental justice and sustainability. In Handbook of Sustainable Development; Atkinson, G., Dietz, S., Neumayer, E., Eds.; MPG Books Ltd: Cornwall, UK, 2007; pp. 171-188. 